\title{
Conservation paleobiology on Minami-Daito Island, Okinawa, Japan: Anthropogenic extinction of cave-dwelling bats on a tropical oceanic island
}

\author{
Yuri Kimura $^{\text {Corresp., } 1,2}{ }$, Dai Fukui ${ }^{3}$, Mizuko Yoshiyuki ${ }^{4}$, Kazuaki Higashi ${ }^{5}$ \\ 1 Department of Geology and Paleontology, National Museum of Nature and Science, Tsukuba, Ibaraki, Japan \\ 2 Institut Català de Paleontologia Miquel Crusafont, ICTA-ICP, Barcelona, Spain \\ 3 The University of Tokyo Hokkaido Forest, Graduate School of Agricultural and Life Sciences, The University of Tokyo, Furano, Hokkaido, Japan \\ 4 Department of Agriculture, Tokyo University of Agriculture, Atsugi, Kanagawa, Japan \\ 5 Office Key Point, Minami-Daito, Okinawa, Japan \\ Corresponding Author: Yuri Kimura \\ Email address: ykimura@kahaku.go.jp
}

Background. With strong environmental and geographic filtration, vertebrates incapable of flying and swimming are often extirpated from island ecosystems. Minami-Daito Island is an oceanic island in Okinawa, Japan that harbors the Daito flying fox (Pteropus dasymallus daitoensis), a subspecies of the fruit bat and the only extant mammal endemic to the island. However, the skeleton of a cave-dwelling bat Rhinolophus sp. and fossil guano were briefly reported in a previous study.

Methods. Here, we present evidence for the anthropogenic extirpation of two species of cave-dwelling bats (Miniopterus sp. \& Rhinolophus sp.) from Minami-Daito Island. Our goal is to reliably constrain the ages of the extirpated bat species by a multiproxy approach. Because skeletal materials did not preserve sufficient bone collagen for direct radiocarbon dating, we alternatively examined guano-like deposits based on SEM observation and Fourier-transform infrared spectroscopy (FTIR) along with stable carbon and nitrogen isotope analyses for possible indirect dating. We also examined stable carbon isotopes in bone apatite, assuming that an isotopic signal of $\mathrm{C}_{4}$ plants on the bat bones links to sugarcane plantation on the island based on the historical knowledge that early human settlers quickly replaced the island's native $C_{3}$ forests with sugarcane $\left(C_{4}\right.$ perennial grass) plantation from 1900 onward.

Results. Our cave survey documents the remains of Miniopterus sp. from the island for the first time. Based on the unique taphonomic conditions (unpermineralized bones, disarticulated skeletons closely scattered without sediment cover, various degrees of calcite crystal growth around bones) and a radiocarbon age of a humic sample, we suggest that the maximum age constraint of Miniopterus sp. and Rhinolophus sp. is 4,640 calBP. Based on a series of analyses, we conclude that the guano-like deposits are composed not of bat guano but mainly of humic substances; however, a hydroxyapatite crust associated with bat-lying stalagmites may be derived from bat feces. Stable carbon isotope analysis of bone apatite revealed $\mathrm{C}_{4}$ signals in various degrees, confirming that small populations of cave-dwelling bats persisted on Minami-Daito Island after 1900.

Conclusions. The results of this study indicate that these populations remained rather small and did not leave many generations and that the estimated ages can be bracketed from 4,640 calBP to the post-1900 (perhaps, until the 1950s). They likely faced a continuously high mortality risk due to severe anthropogenic stresses on the island, where most of the forests were turned into sugarcane plantations

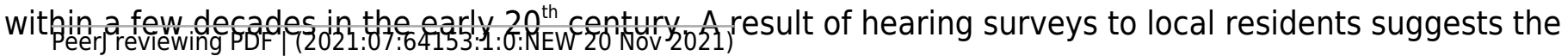


latest remnants most likely disappeared on the island concurrently with the introduction of chemical pesticides after World War II. 
2

3 Conservation paleobiology on Minami-Daito Island, Okinawa, Japan: Anthropogenic extinction

4 of cave-dwelling bats on a tropical oceanic island

5

6

7

8

Yuri Kimura https://orcid.org/0000-0002-7621-9901

Dai Fukui https://orcid.org/0000-0002-5449-4283

14

15

${ }^{1}$ Department of Geology and Paleontology, National Museum of Nature and Science, 4-1-1

${ }^{2}$ Institut Català de Paleontologia Miquel Crusafont, ICTA-ICP. Edifici Z. Carrer de les

21 Columnes, s/n., Campus de la Universitat Autònoma de Barcelona. E-08193 Cerdanyola del

22 Vallès, Barcelona, Spain

23

$24{ }^{3}$ The University of Tokyo Hokkaido Forest, Graduate School of Agricultural and Life Sciences, 25 The University of Tokyo, 9-61, Yamabe-Higashimachi, Furano, Hokkaido 079-1563, Japan 26

${ }^{4}$ Department of Agriculture, Tokyo University of Agriculture, 1737 Funako, Atsugi, Kanagawa 28 243-0034, Japan

29 


\section{Keywords}

36 Anthropogenic extinction; extirpation; Chiroptera; Mammalia; Conservation paleobiology;

37 Zoology; stable carbon isotopes; FTIR; fossil guano

\section{Abstract}

Background. With strong environmental and geographic filtration, vertebrates incapable of flying and swimming are often extirpated from island ecosystems. Minami-Daito Island is an oceanic island in Okinawa, Japan that harbors the Daito flying fox (Pteropus dasymallus daitoensis), a subspecies of the fruit bat and the only extant mammal endemic to the island. However, the skeleton of a cave-dwelling bat Rhinolophus sp. and fossil guano were briefly reported in a previous study.

Methods. Here, we present evidence for the anthropogenic extirpation of two species of cavedwelling bats (Miniopterus sp. \& Rhinolophus sp.) from Minami-Daito Island. Our goal is to reliably constrain the ages of the extirpated bat species by a multiproxy approach. Because

52 skeletal materials did not preserve sufficient bone collagen for direct radiocarbon dating, we

53 alternatively examined guano-like deposits based on SEM observation and Fourier-transform

54 infrared spectroscopy (FTIR) along with stable carbon and nitrogen isotope analyses for possible

55 indirect dating. We also examined stable carbon isotopes in bone apatite, assuming that an

56 isotopic signal of $\mathrm{C}_{4}$ plants on the bat bones links to sugarcane plantation on the island based on

57 the historical knowledge that early human settlers quickly replaced the island's native $\mathrm{C}_{3}$ forests

58 with sugarcane $\left(\mathrm{C}_{4}\right.$ perennial grass $)$ plantation from 1900 onward. 
59 Results. Our cave survey documents the remains of Miniopterus sp. from the island for the first

60 time. Based on the unique taphonomic conditions (unpermineralized bones, disarticulated

61 skeletons closely scattered without sediment cover, various degrees of calcite crystal growth

62 around bones) and a radiocarbon age of a humic sample, we suggest that the maximum age

63 constraint of Miniopterus sp. and Rhinolophus sp. is 4,640 calBP. Based on a series of analyses,

64 we conclude that the guano-like deposits are composed not of bat guano but mainly of humic

65 substances; however, a hydroxyapatite crust associated with bat-lying stalagmites may be

66 derived from bat feces. Stable carbon isotope analysis of bone apatite revealed $\mathrm{C}_{4}$ signals in

67 various degrees, confirming that small populations of cave-dwelling bats persisted on Minami-

68 Daito Island after 1900.

69 Conclusions. The results of this study indicate that these populations remained rather small and

70 did not leave many generations and that the estimated ages can be bracketed from 4,640 calBP to

71 the post-1900 (perhaps, until the 1950s). They likely faced a continuously high mortality risk due

72 to severe anthropogenic stresses on the island, where most of the forests were turned into

73 sugarcane plantations within a few decades in the early $20^{\text {th }}$ century. A result of hearing surveys

74 to local residents suggests the latest remnants most likely disappeared on the island concurrently

75 with the introduction of chemical pesticides after World War II. 
Introduction

81

Insular systems such as remote islands, volcanic lakes, and deep caves, have offered natural testing grounds for understanding how migration, speciation, and extinction function in the long-term ecological dynamics of life (van der Geer et al., 2010). Generally, vertebrate animals capable of flying, swimming, or more passively rafting in water compose native faunas in these systems, and geographic barriers and environmental filters yield species-poor communities with a high percentage of endemic taxa (e.g., Albert et al., 2017; van der Geer et al., 2010). In these settings, human colonization has increased extinction risks of native species by economic activities and bringing introduced species in the natural ecosystem. Thus, long-term monitoring and quantification of species richness and biodiversity on these islands have gained recent attention regarding conservation against further anthropogenic extinction (e.g., Allentoft a et al., 2014; Wood et al., 2017; Carpenter et al., 2020).

The Daito Islands in Japan are an archipelago of oceanic islands that have been separated from the closest landmass since their emergence. Historically, these islands were uninhabited by humans until the first exploitation over 120 years ago in 1899-1900. Prior to the arrival of humans, dense native forests comprising subtropical fan palm trees (Livistona chinensis var. amanoi), Neolitsea sericea var. argentea, banyans, and the evergreen shrub (Excoecaria formosana var. daitoinsularis) harbored endemic species of birds, insects, and fruit bats. By the 1930s, the rapid development of sugarcane plantation along with the filling of underground caves and sinkholes for land improvement and military construction caused severe and irreversible

101 changes in vegetation (Editorial Committee of the History of Minami-Daito Village, 1990). At 
102 present, any remaining natural forests are limited to the rims of the islands (Fig. 1A; Google

103 Earth, 2021). Under a combination of high anthropogenic stresses and biogeographical

104 constraints, the Daito flying fox (Pteropus dasymallus daitoensis), a subspecies of the Ryukyu

105 flying fox (Pteropus dasymallus), is the only extant mammal species endemic to the Daito

106 Islands.

107 Although the endangered Daito flying fox is the only native mammal on the Daito Islands

108 today, Shimojana (1978) reported a skeleton of a cave-dwelling bat species found in Hoshino

109 Cave, the only tourist cave on Minami-Daito Island, and classified the skeleton as Rhinolophus

110 sp. Shimojana (1978) also noted that large amounts of fossil bat guano were present in the cave.

111 Cave-dwelling bats, including fossils and extant ones, have not been documented on the island

112 since then. Recently, based on information about additional skeletons of insectivorous bats in a

113 different cave on the same island, we collected skeletal remains that belong to two bat species of

114 different sizes.

115 In this study, we aim to constrain the ages of the extirpated bat species using a

116 multiproxy approach. Unfortunately, bone collagen was not preserved in the collected bat bones

117 (details in the Materials and Methods section), which makes direct radiocarbon dating

118 impossible. Alternatively, for indirect radiocarbon dating, we examined (1) the guano-like

119 deposits based on SEM observation and Fourier-transform infrared spectroscopy (FTIR) along

120 with stable carbon and nitrogen isotope analyses to test the hypothesis that the "guano deposits"

121 observed by Shimojana (1978) are truly fossil bat guano and (2) conduct stable carbon isotope

122 analysis in bone apatite of the bats to detect a signal of $\mathrm{C}_{4}$ plants. Stable carbon isotopes in bone

123 apatite reflect consumed diet of the bats and are not directly related to age determination. For age

124 constraints of the extirpated bats, we take advantage of the historical fact that the island's native 
$125 \mathrm{C}_{3}$ forests were quickly deforested and replaced with sugarcane $\left(\mathrm{C}_{4}\right.$ perennial grass $)$ plantation

126 from the first development by early human settlers from 1900 onward (details in the Materials

127 and Methods section). It is assumed here that a signal of $\mathrm{C}_{4}$ plants in the bat bones was caused by

128 the presence of sugarcane plantation on the island and thus that the bat individuals were alive

129 after 1900 . We further discuss that the extirpation of the cave-dwelling bats was probably caused

130 by high anthropogenic stresses on the small island.

131

132

133

134 


\section{Geological Setting}

The Daito Islands are oceanic islands located on the Philippine Sea Plate, nearly $400 \mathrm{~km}$ southeast of Okinawa Island in Okinawa Prefecture, Japan, comprising Minami-Daito Island

139 (Minamidaitōjima, $30.74 \mathrm{~km}^{2}$ ), Kita-Daito Island (Kitadaitōjima, $12.71 \mathrm{~km}^{2}$ ), and Oki-Daito

140 Island (Okidaitōjima, 1.19km²), listed in order of decreasing surface area (Fig. 1A-B; Editorial

141 Committee of the History of Minami-Daito Village, 1990). Oki-Daito Island is uninhabitable

142 because of decades of firing exercises by the United States Navy, so ecological studies have only

143 been conducted on Minami-Daito Island and Kita-Daito Island. The Daito Islands are atolls that

144 drifted to its current position from near the equator where coral reefs began to accumulate over

14550 million years ago (Klein and Kobayashi, 1980; Seno and Maruyama, 1984) and were uplifted

146 during the Pliocene and Pleistocene epochs on the forebulge of the Philippine Sea Plate prior to

147 subduction along the Ryukyu Trench (Ohde and Elderfield, 1992). Based on samples from

148 boring surveys on Kita-Daito Island between 1934 to 1936, the carbonate deposits on the islands

149 are up to $430 \mathrm{~m}$ thick, and the oldest strata are early Miocene in age (Ohde and Elderfield, 1992).

150 On Minami-Daito Island, Urushibara-Yoshino (2012) recognized two informal

151 lithostratigraphic units of dolomitized limestone on the island, including the "Lower Daito

152 Layer" and the more fossiliferous "Upper Daito Layer," which are separated by an unconformity

153 that was interpreted as the surface of karstification. Differential erosional rates of the dolomitized

154 limestone layers have formed the unique topography of Minami-Daito Island that is

155 characterized by basin-shaped lowlands ("Hagu Shita" in local vernacular) of the heavily

156 karstified Lower Daito Layer surrounded by topographic highlands ("Hagu Ue" in local

157 vernacular) of the Upper Daito Layer averaging 40m above sea level that form rims along the 158 coast (Urushibara-Yoshino, 2012; Nambu, 2003). A coastal bench $\sim 10 \mathrm{~m}$ above sea level is 
159 overlain by a thin coral limestone dated to $\sim 125 \mathrm{ka}$, corresponding to the Marine Isotope Stage

160 5e during the last interglacial period in the Pleistocene (Ota et al., 1991), whereas the lowest

161 coastal bench at $\sim 3 \mathrm{~m}$ above sea level may have formed more recently during a mid-Holocene

162 sea-level highstand, the age of which is 6,500-5,000 BP (Umitsu, 1991 for ages; Urushibara-

163 Yoshino, 2012).

164

165 
Materials and Methods

\section{Skeletal remains in the caves of Minami-Daito Island}

There are countless sinkholes (dolines) and caves on Minami-Daito Island, some of which preserve the remains of extirpated bats. We collected vertebrate skeletal remains and bat guano-like deposits from two of these caves, which are a public cave called Hoshino Cave (also called Hoshinodō or Hoshinodo Cave, as "dō" means "cave" in Japanese) and a privately-owned cave informally called "Cave A" (Fig. 1A). Fieldwork was conducted in January 2016 and January 2018 because the $\mathrm{CO}_{2}$ concentration levels in the caves are lowest during the winter. All fieldwork was conducted outside national parks or restricted areas designated by the Nature Conservation Act.

Cave A is accessible via several spots where the ceiling has collapsed, but we entered through the main natural entrance, which is located in the Hagu Shita basin near the basin-side edge of the Hagu Ue rim (Fig. 1C). Because there is no published map for Cave A, we made a

183 simple route map from the main entrance to our sample locations (Fig. 1D). Skeletal remains of

184 insectivorous bats were collected from a small hall about $60 \mathrm{~m}$ north of the main entrance.

185 Generally, skeletal remains are scattered, suggesting that these individuals were not transported

186 by water flow (Fig. 2A-B). In Cave A, we observed that at least four individuals were almost

187 completely articulated and embedded by thin crusts of flowstone, which have served as

188 protection against dissociation and bone decay (Fig. 3). Two of these individuals were collected

189 (Fig. 2D). For others, bones are disarticulated and selectively preserved with a bias toward long

190 bones (radius, metacarpal, etc.), tympanic bullae, and jaws. In Hoshino Cave, we entered from a 
191 natural entrance, which is not open to the public, and found an incomplete skeleton of one

192 individual of Rhinolophus sp. several meters below a paved commercial route (Fig. 1E).

193 Fragile bones were reinforced in the lab by coating with a solution of 5\% Paraloid B-72

194 dissolved in acetone. They are stored at the National Museum of Nature and Science, Tokyo

195 (NMNS; Tsukuba, Ibaraki, Japan). A complete list of collected bones is provided in Table 1, and

196 a detailed taxonomic study of the specimens is in progress.

197 Some well-preserved fragments without secondary calcite crystal growth or acid etching

198 were consumptively sampled for radiocarbon dating; however, none preserved collagen (i.e., no

199 signal was detected for nitrogen using Elemental Analysis [EA] on a bone fragment), so these

200 materials were not useful for direct dating. Because we were unable to determine the age of any

201 individual fossil, we instead examined guano-like deposits accumulated in the same caves for

202 time-averaged ${ }^{14} \mathrm{C}$ ages.

203

204

205

206

207

208

209 
210 Guano-like deposits on Minami-Daito Island

211 Guano-like deposits were sampled at four localities in Cave A (Fig. 1D) and one locality

212 in Hoshino Cave (Fig. 1E). These deposits are accumulated in piles on the floors of the caves

213 that can be washed downslope. They are soft muddy sediments brownish-black (10YR2/2 to

214 10YR2/3) to black (10YR2/1) in color. Mud particles are loosely coalesced to form sand-sized

215 granules, which are often contaminated with dolomite fragments. They are also present in local

216 small depressions above the floor. Flowstones in the caves are often colored black from pollution

217 in areas where the Japanese military used them as headquarters during World War II (WWII;

218 "Headquarter Hall" on the map) and where groundwater drains. We collected guano-like

219 deposits from large piles (Fig. 4A) or handpicked coalesced particles using forceps (Fig. 5A).

220 The largest pile of guano-like deposits (8 10m wide on the surface) was found in Hoshino Cave,

221 which is probably the deposit noted by Shimojana (1978). The thickness of the pile is over $50 \mathrm{~cm}$

222 at a random spot where we collected samples from its bottom, a mid-part, and its top. There is no

223 sedimentological difference observed except that the bottom sample contained more carbonate

224 lithic fragments. In Cave A, a thin crust under a bat-lying flowstone was also sampled (Figs. 5B,

225 5D). The sampled deposits were dried in a convection oven at $38^{\circ} \mathrm{C}$ and were sieved at $850 \mu \mathrm{m}$,

$226425 \mu \mathrm{m}$, and $250 \mu \mathrm{m}$. Samples between $250 \mu \mathrm{m}$ and $425 \mu \mathrm{m}$ were carefully handpicked using

227 forceps for black particles to avoid carbonate contamination prior to further analyses.

228 Because insectivorous bats consume arthropods (crickets, beetles, moths, etc.), bat guano

229 contains their chitinous exoskeletons, which are resistant to decay. We utilized established

230 signals of the chitinous exoskeletons of arthropods to determine whether or not the guano-like

231 deposits are guano-derived by comparison with modern and fossil bat guanos as positive

232 references and red soil as a negative reference. The red soil was collected from the bottom of

233 thick soil deposits beneath a fissure in Cave A.

Peer] reviewing PDF | (2021:07:64153:1:0:NEW 20 Nov 2021) 


\section{Modern and subfossil bat guano as positive references}

236 For comparison with the guano-like deposits sampled in Hoshino Cave, we used a

237 commercial guano fertilizer collected in Indonesia (called R1 in figures; ARK Co. Ltd., Ushiku,

238 Ibaraki, Japan), modern bat guano of Miniopterus fuliginosus (R2) from an unnamed artificial

239 cave of soft sandstone in Taito, Isumi, Chiba, subfossil guano deposit (R3) from Fujido Cave in

240 Udeno, Gunma, and fecal pellets (R4) of Vespertilio sinensis in Chichibu, Saitama. Localities

241 were selected by Y.K. for ease of access. These samples were used as "positive references" for

242 comparison with our unknown guano-like samples from the Minami-Daito Island caves (see

243 Supplementary Article S1 for more details).

\section{Scanning Election Microscopy (SEM) observation}

In the fecal pellets of modern insectivorous bats, arthropod exoskeleton fragments are

usually observed. Thus, we imaged dry samples of the guano-like deposits from Hoshino Cave

and the four guano references at the National Museum of Nature and Science (NMNS; Tsukuba,

Ibaraki, Japan) using a JSM-6510 (JEOL Ltd., Tokyo, Japan) scanning electron microscope with gold sputter coating on the dry samples.

\section{Fourier Transform Infrared Spectroscopy (FTIR)}

Fourier transform infrared (FTIR) spectroscopy is a technique commonly used to characterize specific molecular structures in organic compounds. The FTIR spectra of chitin 
258 previous studies (e.g., Wurster et al., 2010; Kaya et al., 2014), so we used FTIR to identify

259 whether chitin is a major component of the guano-like deposits. The hand-picked samples of the

260 guano-like deposits and reference materials (modern and fossil guano, red soil) were refluxed

261 with $1.0 \mathrm{M} \mathrm{HCl}$ at $80^{\circ} \mathrm{C}$ for at least 8 hours to remove exogenous carbonates and organic acids

262 (e.g., fluvic acids) and were rinsed with deionized water until the solvent became a neutral $\mathrm{pH}$.

263 After drying in a convection oven below $38^{\circ} \mathrm{C}$, the samples were ground in an agate mortar with

264 a pestle. They were then stored in a desiccator at room temperature until analysis.

265 Each powdered sample was diluted with ground $\mathrm{KBr}$, pressed into a pellet in a stainless-

266 steel disk, and analyzed without a vacuum using a JASCO FT/IR-6800 (JASCO Inc., Tokyo,

267 Japan) at NMNS. Pure KBr was measured as the background under the same conditions as the

268 samples. The infrared spectra of absorbance were measured from $400 \mathrm{~cm}^{-1}$ to $4000 \mathrm{~cm}^{-1}$ by 64

269 scans at a resolution of $4 \mathrm{~cm}^{-1}$ and are expressed as the percentage of transmittance $(\% \mathrm{~T})$.

270 Automatic baseline corrections were made using a second-degree polynomial fitting $\left(\mathrm{x}^{2}\right)$.

271

272 Stable isotope analyses and $\mathrm{C}: \mathbf{N}$ ratio of the guano-like samples

273 To supplement FTIR results of the guano-like samples, we measured stable carbon and

274 nitrogen isotope values and mass ratios of organic carbon to nitrogen $(\mathrm{C}: \mathrm{N})$ for the HCl-treated

275 samples using a FLASH 2000 CHNS/O elemental analyzer coupled with a Finnegan MAT253

276 isotope ratio mass spectrometer (Thermo Fisher Scientific, Massachusetts, USA) at NMNS.

277 Isotopic ratios are expressed in delta notation $\left(\delta^{13} \mathrm{C}, \delta^{15} \mathrm{~N}\right)$ in parts per thousand (\%o) and reported

278 on the VPDB scale for $\delta^{13} \mathrm{C}$ values and the AIR scale for $\delta^{15} \mathrm{~N}$ values. For guano-like deposits, a

279 thick sample from Hoshino Cave and a handpicked pellet-like sample from Cave A were selected

280 for analysis. Three internal lab standards were analyzed for each run and used for data

281 correction. Repeated analyses of the standards were within $\pm 0.2 \%$ for $\delta^{13} \mathrm{C}$ and $\pm 0.25 \%$ for 
$282 \delta^{15} \mathrm{~N}$. Carbon isotope values of guano references are used to reconstruct isotopic signals of their

283 diet by taking the following isotope fractionation factors into consideration. The fractionation

284 factor between the feces of insectivorous bats and their diet (i.e., insects) is known to be

285 negligible (Salvarina et al., 2013), whereas larger fractionation factors are observed between the

286 cuticles of insects and their diet of plant matter. In an experimental study, Gratton and Forbes

287 (2006) showed that tissues of predacious beetles are more enriched by $2.2 \%$ relative to their 288 aphid diet.

289

290 Stable carbon isotopes of bone apatite

291

Stable carbon isotope analysis of animal tissues is a useful technique to detect an isotopic

292 signal of $\mathrm{C}_{4}$ plants in their habitat. Although no $\mathrm{C}_{4}$ plant is native to the Daito Islands, historical

293 records (Editorial Committee of the History of Minami-Daito Village, 1990) document that the

$294 \mathrm{C}_{4}$ perennial grass sugarcane was introduced on Minami-Daito Island in 1899-1900 and

295 increasingly replaced native $\mathrm{C}_{3}$ forests on the island by the 1930s (see Introduction). We

296 therefore hypothesize that any organic materials on the island with the isotopic signature of $\mathrm{C}_{4}$

297 plants must have originated after the introduction of sugarcane in 1899-1900. Thus, stable

298 carbon isotope analysis with correct applications of fractionation factors can serve as a time

299 constraint for direct human influences on Minami-Daito Island. Note that no scientific study such

300 as palynological analysis of sediment cores is available to independently validate the historical

301 documents.

302 Relatively well-preserved bat bones (no acid etching, no or limited calcite crystallization)

303 from Cave A were selected for carbon isotope analysis of bone apatite. For each bone, the

304 surface was shaved off to remove calcite crystals and carbonate deposits as much as possible 
305 from the thin bones. The powdered samples were soaked in $2 \% \mathrm{NaOCl}$ overnight for at least 12

306 hours at the room temperature. After rinsing with deionized water, they were treated with

307 buffered $0.1 \mathrm{M}$ acetic acid $(\mathrm{pH}=4.2)$ for 2 hours at $40^{\circ} \mathrm{C}$ until no obvious bubbles were observed,

308 and they were neutralized with ultrapure water and dried in an oven at $40{ }^{\circ} \mathrm{C}$. The treated

309 samples were sent to Shoko Science Co., Ltd. (Saitama, Japan) and analyzed for stable carbon

310 isotope via a $\mathrm{H}_{3} \mathrm{PO}_{4}$ digestion using by a continuous flow Thermo Scientific Delta V Plus isotope

311 ratio mass spectrometer coupled to a Thermo Scientific GasBench II. Of the eight samples

312 analyzed in this study, seven come from individual bones, whereas one sample is composed of

313 multiple small bone fragments.

314 The carbon isotope values of bone apatite were used to reconstruct isotopic signals of

315 vegetation by applying experimentally known enrichment factors $\left(\varepsilon^{*}\right)$ and binary mixing

316 between $\mathrm{C}_{3}$ - and $\mathrm{C}_{4}$-endmembers. The enrichment factor applied in this study is $+11.0 \pm 0.1 \%$

317 between bone apatite and insectivorous diet (Podlesak et al., 2008). For isotopic spacing $(\Delta)$

318 between insectivorous diets of bats and surrounding vegetation, we applied $+2.2 \%$ or $+3.0 \%$

319 based on an a dietary-switch experimental study by Gratton and Forbes (2006). For the end-

320 members in binary mixing, $\delta^{13} \mathrm{C}$ values of $-12.5 \%$ and $-29.1 \%$ were used for pure $\mathrm{C}_{4}(\mathrm{Cerling}$ et

321 al., 1997) and $C_{3}$ vegetation, respectively. The latter was calculated based on the equation of

322 Kohn (2010), which takes mean annual precipitation (MAP), altitude, and latitude into account.

323 MAP of Minami-Daito Island between 1942 and 2020 was calculated as $1680 \mathrm{~mm} /$ year, which

324 was applied to the equation. See Supplementary Article S1 for more details.

325

326

327

\section{Radiocarbon dating of subfossil guano references}

We determined the ${ }^{14} \mathrm{C}$ age of both the fossil guano reference (R3) and the guano-like

328 samples for comparison. The same samples analyzed for stable isotopes were chosen for 
329 radiocarbon dating. Prepared samples were sent to the accelerator mass spectrometry (AMS)

330 facility at the University Museum, the University of Tokyo, where the samples were further

331 prepared and measured by Compact AMS System (National Electrostatics Corp., Wisconsin,

332 USA), following their in-house protocols (Omori et al., 2017). For each sample, $\delta^{13} \mathrm{C}$ measured

333 by AMS was used to correct for the conventional radiocarbon age (Stuiver and Polach, 1977).

334 These radiocarbon ages were calibrated by IntCal20 curves (Reimer et al., 2020) in OxCAL4.2

335 (Bronk Ramsey, 2009) and are expressed as calBP (Before Present; 0 calBP = AD 1950).

336 Preparation and analytical methods are described in Supplementary Article S1.

337

338

339

340 


\section{RESULTS AND DISCUSSION}

343

344 Skeletal remains of locally extinct cave-dwelling bats

In a survey during the 1970s, Shimojana (1978) reported a few skeletons of Rhinolophus

346 sp. from Hoshino Cave. In this study, we found the skeletons of single individuals of

347 Rhinolophus sp. in both Hoshino Cave and Cave A. Additionally, we collected skeletons of

348 Miniopterus sp. from Cave A, which represent at least 13 individuals (taxonomic study in

349 progress). Some skeletons are articulated, but many are disconnected with associated bones

350 closely scattered on the surface of the cave floor (Fig. 2), so we infer that they were not

351 transported by water after death. No traces of soft tissues such as pelage are preserved. In Cave

352 A, we observed at least four individuals of Miniopterus sp. that were embedded within a thin

353 crust of flowstone (Fig. 3), two of which were collected. No fossil remains are permineralized,

354 but many are encrusted with calcite. The condition of calcite crystal growth on and in bones

355 depends on the availability of mineral-rich water flow near the bones. In many bone materials,

356 the surface is partially covered with small calcite crystals, and/or the medullary cavity of long

357 bones is partially infilled.

358 Due to the lack of bone collagen for radiocarbon dating in the specimens we sampled, it

359 is unknown whether these bat species utilized the cave contemporarily; however, because there is

360 no difference in bone preservation and secondary crystal growth of calcite between the two

361 species, our paleontological interpretation is that the ages of their existences do not differ even if

362 they may not be coeval sensu stricto.

363

364

365 SEM observation of guano-like samples 
367 fossil guano references (Fig. 4G) at or above 70x magnification although the fossil guano is

368 degraded to be humus-like and contaminated with sediments (Fig. 4F). On the other hand, the

369 guano-like samples appear to be aggregates of clay-sized particles with no clear presence of

370 insect remains (Figs. 4B-4C), suggesting that they may not be composed of bat guano.

371 Nevertheless, because the preservation potential of chitinous insect remains is expected to be

372 lower in guano deposits from tropical wet caves like those on Minami-Daito Island than in the

373 fossil guano reference collected from a more temperate region, we proceeded with further

374 analyses.

375

376

377

378

379

380

381

382

383

384

385

386

387

388

389

\section{FTIR}

None of the guano-like deposits collected in this study present spectral patterns characteristic of fresh or fossil guano (Figs 6, 7, see Supplementary Article S1 for full description of references). In the range between $1000 \mathrm{~cm}^{-1}$ and $1800 \mathrm{~cm}^{-1}$, different spectral patterns are observed between guano references and sampled deposits. Particularly, a shoulder peak at $1712 \mathrm{~cm}^{-1}$ associated with $\mathrm{C}=\mathrm{O}$ stretching of carboxylic acid (Dick et al., 2003) is present in guano-like samples but does not occur in the spectra of guano references (Fig. 6). This peak occurs in humified organic matter (Dick et al. 2003; Palumbo et al., 2018).

The FTIR spectrum of the guano-like sample Y180119g3 (Fig. 6D) is comparable to that of humic acid (Figs. 6H-6I). The absorption at $1078 \mathrm{~cm}^{-1}$ is ascribed to the stretching vibration of oxygen bonds in aliphatic ether (Zhang et al., 2015). The presence of aliphatic compounds is consistent with the interpretation that this sample is a fraction of humic substances (Méndez, 1967). The peak at $1244 \mathrm{~cm}^{-1}$ can be interpreted as antisymmetric $\mathrm{C}-\mathrm{O}$ stretching and $\mathrm{OH}$ 
390 deformation in a carboxyl group, and -C-OH bending of phenols and tertiary alcohol in humic

391 substances (Dick et al., 2003). As organic functional groups, carboxylic acids are contained in

392 humic substances. We interpret that the guano-like deposits sampled in this study are forms of

393 humic substances rather than fossil bat guano, with the exception of Y160114g1, which was

394 identified as hydroxyapatite (Fig. 7D) by comparing characteristic spectral peaks with those of

395 pure hydroxyapatite in Jayaweera et al. (2018).

396 The hydroxyapatite sample, Y160114g1, occurs as a thin crust light brown in color only

397 partially exposed under a fracture of more recent flowstone on the slope of a large stalagmite

398 (Fig. 5B). Interestingly, we found skeletal remains of at least two individual bats lying on a slope

399 of the stalagmite, both of which are also covered by recent flowstone (Fig. 3B). The

400 hydroxyapatite crust stratigraphically underlies the bat skeleton. As a calcium phosphate mineral,

401 hydroxyapatite is commonly precipitated in caves where phosphorous-rich organic deposits such

402 as bat guano or bones are supplied and interaction between the guano-derived leachate and

403 calcium-rich water from carbonate host-rock can occur at a pH greater than 6 (Fiore and

404 Laviano, 1991; Hill and Forti 1997; Tămaş et al. 2014; Giurgiu and Tămaş, 2013). Because this

405 hydroxyapatite crust was found in association with a bat skeleton, and hydroxyapatite

406 precipitation is inhibited in the presence of humic and fluvic acids (Inskeep and Silvertooth,

407 1998), this crust was likely derived from bat guano rather than humified plant material. 408 409

\section{$410 \mathrm{C}: \mathrm{N}$ ratios, $\boldsymbol{\delta}^{\mathbf{1 3}} \mathbf{C}$, and $\boldsymbol{\delta}^{\mathbf{1 5}} \mathbf{N}$ values of the guano-like samples}

411 The $\mathrm{C}: \mathrm{N}$ ratios, total nitrogen by weight percent $(\% \mathrm{~N}), \delta^{13} \mathrm{C}$ values, and $\delta^{15} \mathrm{~N}$ values of

412 the guano-like samples are shown in Fig. 8 (Tables 2, S1). In the bulk sample of the fissure-filled

413 deposit, total nitrogen is nearly $0.1 \%$, which is within the standard range of nitrogen content for 
414 sediments (Forbes and Bestland, 2006). The nitrogen content in the fecal pellet-like sample

415 Y180119g2 (Fig. 5A) from Cave A is lower than the $\% \mathrm{~N}$ range of guano references (Fig. 8A).

416 Because the FTIR spectrum of the pellet-like sample similarly traces that of the fissure-filled

417 deposit, we interpret that the fecal pellet-like sample is a mix of sediment and organic matter. In

418 general, C:N ratios of all analyzed samples are tightly clustered, ranging from 4.2 for fissure-

419 filled deposit to 6.5 for the fossil guano reference with the unknown guano-like samples (4.8 on 420 average) equivalent to those of modern guano (R1 and R2) (Fig. 8B). These values are much

421 lower than fresh plants and coals (e.g., Schmidt and Gleixner, 2005) and superficially meet one

422 of Forbes and Bestland's (2006) criteria to identify fossil guano $(\mathrm{C}: \mathrm{N}<10)$. Nevertheless, in our

423 case, the low $\mathrm{C}: \mathrm{N}$ values of the samples are still consistent with the FTIR-based classification of

424 the red soil of the Minami-Daito Islands as a lateritic soil because it is known that $\mathrm{C}: \mathrm{N}$ ratios in

425 humic substances and soil organic matter extracted from modern lateritic soil show roughly

426 comparable values between 7 and 10 (Dick et al., 2003).

427 The $\delta^{13} \mathrm{C}$ values of guano references range from $-28.2 \%$ to $-19.1 \%$, encasing the guano-

428 like samples (mean $\pm 1 \mathrm{SD}=-26.4 \pm 0.22 \%$ ) (Fig. $8 \mathrm{~B}$ ). Accounting for the isotopic spacing among

429 bat guano, their insectivorous diet, and surrounding vegetation, the guano-like deposits are well

430 within the range of $\mathrm{C}_{3}$ plants, which exhibit a general range from $-23 \%$ to $-37 \%$ in non-desert

431 areas (Kohn, 2010). As they completely lack a signal of $\mathrm{C}_{4}$ plants, we suggest that these deposits

432 were formed before anthropogenic influences because sugar cane, $\mathrm{C}_{4}$ perennial grass, became

433 exclusively dominant by the 1930 s due to heavy cultivation on the island.

434 The $\delta^{15} \mathrm{~N}$ values of the referenced guano samples widely range from $3.0 \%$ to $11.6 \%$,

435 placing the guano-like deposits from Hoshino Cave in its mid-range and the fecal pellet-like

436 sample from Cave A close to its upper limit (Fig. 8A). Forbes and Bestland (2006) used high 
$437 \delta^{15} \mathrm{~N}$ values above $12 \%$ in association with low $\mathrm{C}: \mathrm{N}$ ratios below 10 and high contents of

$438 \mathrm{SO}_{3}+\mathrm{P}_{2} \mathrm{O}_{5}+\mathrm{CaO}$ to identify a potential guano layer in accumulated cave deposits. The $\delta^{15} \mathrm{~N}$

439 values of the guano-like samples from Hoshino Cave do not meet their criteria although neither

440 do those of some guano references. Overall, as in the case of $\% \mathrm{~N}$ and $\mathrm{C}: \mathrm{N}$ ratios, stable carbon

441 and nitrogen isotopes were not good indices to identify bat guano in caves of tropical islands

442 where lateritic soil can be developed.

443

444

445

446

447

448

449

450

451

452

453

454

455

456

457

458

459

460 Group size and estimated ages of cave-dwelling bats on the Daito Islands

Stable carbon isotopes of bone apatite

Bone apatite $\delta^{13} \mathrm{C}$ values ( $\mathrm{n}=8$ ) show a wide range from $-15.0 \%$ to $-8.36 \%$ with a mean of $11.5 \pm 2.38 \%$ ( $( \pm 1 \mathrm{SD})$ (Table 3$)$. Figure 9A shows estimated isotopic signals of vegetation, calculated from carbon isotope values of bone apatite of bats. Considering that fractionation factors and isotope values in the mixing model are reasonably assumed (see Supplementary Article S1), $\mathrm{C}_{4}$-feeding insects explains more than $10 \%$ of the total diet in six out of the eight individuals analyzed in this study even with a large isotopic spacing between predatory insects and plants (open circle in Fig. 9A). On average, the estimated $\delta^{13} \mathrm{C}$ value of bulk plants is $25.4 \%$ (open circle), which is translated to $22 \%$ of $\mathrm{C}_{4}$ plants in the simple mixing model. On Minami-Daito Island, $\mathrm{C}_{4}$ plants were introduced only by humans via sugarcane plantations. Therefore, the unmistakable isotopic signal of $\mathrm{C}_{4}$ plants demonstrates that these individuals coexisted with humans after 1900 . 
Two locally extinct bat species, Miniopterus sp. and Rhinolophus sp., once existed in the

462 lifted atoll remotely located from the closest landmass. Based on the number of skeletal remains

463 recovered from Cave A in this study (at least $\mathrm{n}=17$ for Miniopterus $\mathrm{sp}$. and $\mathrm{n}=1$ for Rhinolophus

464 sp.), this cave was utilized by more individuals of Miniopterus sp. than Rhinolophus sp.

465 Considering the taphonomic conditions of the Minami-Daito bats (unpermineralized, exposed on

466 cave floor without any depositional cover, fast crystal growth around bones in tropical wet

467 caves), we interpret that these skeletons are only a few thousand years old at most but probably

468 even younger and that the two species occurred contemporarily in the paleontological sense.

469 FTIR spectra and SEM images suggest that the guano-like deposits on Minami-Daito

470 Island are most reasonably humic substances, which are the final constituent of the

471 physicochemical degradation and microbial decomposition of organic matter, particularly plant

472 materials (Stevenson, 1994). The hydroxyapatite crust under the bat skeleton was possibly

473 formed from the interaction between bat guano and limestone/dolomite. Nevertheless, we reject

474 the null hypothesis that the "guano deposits" observed by Shimojana (1978) are fossil bat guano

475 and deny the presence of large amounts of guano deposits in the caves, which suggests the

476 skeletal remains are not resultant from large populations or those which utilized these caves for 477 generation after generation.

478 Our humic samples from both Hoshino Cave and Cave A yielded similar ages of 4565

479 calBP (on the 3-point average) and 4640 calBP, respectively (Table S2), which we think provide

480 the maximum age constraint for the bat species as the bat bones collected in this study were

481 scattered nearby pellet-like humic particles in Cave A. A better age constraint was provided by

482 stable carbon isotopes of the selected bat bones from Cave A. Isotopic signals of $\mathrm{C}_{4}$ grass- 
483 feeding insects detected in various degrees from six out of eight individuals strongly indicate that

484 some of the sampled bats lived after 1900 (Fig. 9B).

485 In summary, small groups of bats that were dispersed to Minami-Daito Island did not

486 survive long due to strong anthropogenic stresses on the islands. Whether or not their arrivals

487 were caused by a single sporadic event or multiple events is still inconclusive in this study.

488 However, future taxonomic studies and analyses of morphological variation could elucidate the

489 possible biogeographic origins of the strayed populations, which would provide a hint to

490 understand how these species ended up co-occurring on the small island.

491

492

493

\section{Extirpation of two cave-dwelling bat species on the Daito Islands}

Our multiproxy approach to constrain the estimated ages of the Minami-Daito cave-

dwelling bats include hearing surveys of local residents on the Daito Islands. This survey was

conducted by Dr. Hidetoshi Ohta on August 22 and October 28 in 1991 for a different purpose

but happened to provide an imperfect yet interesting perspective regarding the extirpation of the

bats (pers. comm. with H. Ohta on December 31, 2018 by YK and DF). According to his field

notes, three men (Mr. Akamine, Mr. Nakama, Mr. Sunagawa; all in their 80s) commented that

they witnessed "bats smaller than the Daito flying fox" in a cave during the daytime within a few

501

years after the end of WWII. In the second survey, three other men (Mr. Toma, Mr. Suzuki, and

502

Mr. Okiyama; two in their 80 s, one in his 90s) commented that they also saw "baby flying foxes"

in caves near "Hagu (rim)" before WWII. For local residents, the Daito flying fox is a typical

mammal on the island. Thus, these bats are reasonably considered as Miniopterus sp. and/or

Rhinolophus sp., as the Daito flying fox roosts in the canopies of trees during the daytime, not 
507 sometime after WWII, and the very last survivors could have been present until the 1950s, which

508 is consistent with our taphonomic interpretation of the bones.

509 On Minami-Daito Island, the irreversible rapid change from tropical/subtropical forests to

510 sugarcane fields was extraordinary following the arrival of early settlers/residents in 1899-1900

511 with heavy development by the 1930s. In addition to reducing favorable habitats for cave-

512 dwelling bats by opening the land and filling in sinkholes, there would have been other mortality

513 causes. Many caves were used as natural storage and air-raid shelters during WWII. Cave A was

514 a base of the Imperial Japanese Army during WWII. There are metal scraps, glass bottles, and

515 wood plausibly derived from that age. Surface water also transports waste into caves. We found

516 coal-like carbon particles in the guano-like samples while handpicking in the lab, which may be

517 related to wasted carbon derived from old steam locomotives that existed from 1917 to 1983 to

518 transport harvested sugarcane stalks as the railway track was run near Cave A (Kada, 2009).

519 Chemical pesticides were introduced in sugarcane plantations, and the aerial spray of pesticides

520 was conducted at least in the early 1970s (Editorial Committee of the History of Minami-Daito

521 Village, 1990: p.1167). Considering the extremely rapid development on the small island,

522 anthropogenic activities are undeniably responsible for the local extinctions of the last population

523 of the cave-dwelling bat species. It is noted however that the results of our study do not

524 completely exclude the possibility that these bats were non-viable drifting populations that

525 naturally died out without leaving descendants. In the future, this could be tested by finding out

526 how (and whether) other caves on the Daito Islands were utilized by the extirpated bats.

527

528 Conservation paleobiology on tropical oceanic islands 
Using a multidisciplinary approach, we were able to bracket the estimated chronological

530 age of the Minami-Daito cave-dwelling bats, ranging from a maximum constrained age of 4,640

531 calBP (radiocarbon age of humin closely scattered with the bat bones in Cave A) to the 1950s

532 (hearing survey). Stable carbon isotopes of bone apatite provided unmistakable direct evidence

533 that they existed after 1900 and reinforced the hearing survey record.

534 Despite rapid civilization and deforestation on the island throughout the $20^{\text {th }}$ century, the

535 Daito flying fox has been able to survive on the island. The Daito flying fox, which is designated

536 as a critically endangered subspecies (IA) in the National Red Data List of the Ministry of the

537 Environment, Japan (RDB, 2020) and is thus of high concern for species conservation (Vincenot

538 et al., 2017), consumes fruits and nectar of native species such as Chinese banyan (Ficus

539 microcarpa), Fiscus superba var. japonica, Ficus virgala, and fan palm trees (Livistoma

540 chinensis var. amanoi), but it also utilizes windbreak trees and street trees as a food source

541 (Kinjo, 2009). Flexible food preferences may explain how the Daito flying fox has survived

542 throughout anthropogenic damages as in the case of the neighboring subspecies Orii's flying fox

543 (Pteropus dasymallus inopinatus) on Okinawa Island, which utilizes planted trees in urban areas

544 as stable food sources (Nakamoto et al., 2007).

545 Regarding the presence of fossil bat species on an oceanic island, a similar case was

546 reported for an extinct endemic bat, Synemporion keana (lava-tube bat), from the Hawaiian

547 Islands, which are over $3800 \mathrm{~km}$ away from the nearest continental landmass (Ziegler et al.,

548 2016). Synemporion keana is a vespertilionid bat slightly smaller than the extant Hawaiian hoary

549 bat (Lasiurus cinereus semotus) that is known to have inhabited the Hawaiian Islands at least

550 until the earliest Polynesian cultural period because a fossil of $S$. keana was successfully

551 radiocarbon dated to $1670 \mathrm{BP}$ (Ziegler et al., 2016). According to that study and the references 
552 therein, those fossils were recovered from infilled deposits (soil, eolian deposit, pond deposit) or

553 exposed on the floor of limestone sinkholes, volcanic lava tubes, a piping cave, and a volcanic-

554 tuff cone crater. Similar to our studies, those fossils were not suitable for DNA extraction or

555 radiocarbon dating. They estimated a chronological range of the Hawaiian fossil bat species by

556 establishing the ${ }^{14} \mathrm{C}$ ages of both coexisting animal skeletons such as birds and rats and cultural

557 artifacts derived from the same stratigraphic level or nearby and the formation of volcanic caves

558 from which the fossils were found. Another interesting case of the late Holocene $(<4,000 \mathrm{BP})$

559 extirpation of bats is found on a tropical island in the Caribbean (Soto-Centeno and Steadman,

560 2015).

561 In this study, we revealed that two cave-dwelling bat species were extirpated from

562 Minami-Daito Island without any zoological record when they existed. Minami-Daito Island

563 used to be a home of three bat species, but only a single species survived anthropogenic

564 disturbance. Geological, geochemical, and paleontological approaches are useful to bracket

565 chronological ranges of the two extirpated species. Chronological ranges of extirpated species

566 should be estimated with higher accuracy to deduce causality of the local extinction events and

567 subsequently to promote conservation of biodiversity on oceanic islands, which are generally

568 vulnerable to anthropogenic factors.

570

571 Conclusions

572 Minami-Daito Island is an oceanic island that has never been connected to another

573 landmass since its emergence. A few skeletons of Rhinolophus sp. were found during the 1970s

574 from Hoshino Cave, the only tourist cave on the island (Shimojana, 1978). In this study, we

575 found not only an additional skeleton of Rhinolophus sp. from Hoshino Cave but also a skeleton 
576 of the same species and more of Miniopterus sp. from another private cave. Because these bones,

577 which were exposed on the floor of the tropical dolomite caves, did not preserve collagen for

578 radiocarbon dating, we used multidisciplinary proxies to provide time constraints for estimated

579 ages of the bats. Differing from a previous study, we obtained limited witnesses of cave-dwelling

580 bats from before/during WWII and concluded the "guano-like" deposits commonly previously

581 identified were humic substances formed ca. 4640 calBP, which gives the maximum age

582 constraint for the extirpated bats. Their populations were never large and quickly shrank due to

583 rapid and heavy deforestation for sugarcane plantations on the island. They were extirpated from

584 Minami-Daito Island without any zoological record when they existed. This study highlights that

585 anthropogenic activities increase the mortality of animal species newly strayed into insular

586 environments.

587

588

589

590

591

592

593

594

595

596

597

598

599

\section{Acknowledgments}

We deeply appreciate Shin-Ichiro Kawada (National Museum of Nature and Science, Japan for permitting us to access zoological collections at NMNS and assisting with fieldwork and Benjamin T. Breeden III (University of Utah) for providing constructive comments and English proofreading for the early draft. We are thankful to Katsuji Yoshida (Cave Exploration Pro-Guide Team Ciao!), Takeshi Matsushita (Cave Exploration Pro-Guide Team Ciao!), and Yukari Yamaguchi (Cave Exploration Pro-Guide Team Ciao!) for making a route map of Cave A and to Ken Ōyabu and Masaharu Hayakawa (Uekusa Gakuen University \& Junior College) for permitting access to modern bat guano in Taito, Isumi, Chiba. We are grateful to Yushi Osawa, Keiko Osawa, Yu Iijima, and Hiroko Nagaoka for field assistance and to Mika Yagishita and Sonoko Suzuki for lab assistance. Nozomi Suzuki provided us great support for isotope analyses. 
600 We thank Brandon Hedrick for carefully handling our manuscript and J. Angel Soto-Centeno and 601 one anonymous reviewer for constructive comments on the early draft, which improved the 602 quality of the manuscript.

603

604

605 This project was conducted as part of project I+D+i PID2020-117289GBI00 funded by MCIN/

606 AEI/10.13039/501100011033/. Y.K. was financially supported by the Fujiwara Natural History

607 Foundation (2018), the National Museum of Nature and Science as part of a research project

608 called "Chemical Stratigraphy and Dating as a Clue for Understanding the History of the Earth

609 and Life", JSPS KAKENHI Grant Number 18K13650, and the Generalitat de Catalunya

610 (CERCA Programme). D.F. was financially supported by the 26th PRO NATURA FUND, Asahi

611 Glass Foundation, and JSPS KAKENHI Grant Number 20H01979. 


\section{Figure Captions}

613

614 Figure 1. Map of Minami-Daito Island, route map of a privately-owned Cave A, cave map of 615 Hoshino Cave. (A) Satellite map (Google Earth, 2020); (B) Map of Ryukyu Islands; (C)

616 Entrance of Cave A; (D) Route map of Cave A; (E) Map of Hoshino Cave (Simplified from a 617 map of Ehime University Expedition Club, 1972). Solid circles indicate sampling localities of 618 guano-like deposits, and open stars indicate sampling localities of cave-dwelling bat bones.

619 Figure 2. Various conditions of skeletal remains of Miniopterus sp. (A) partially articulated, not 620 covered by flowstone; (B) complete skull with fragmentary bones, not covered by flowstone; (C)

621 partially articulated, covered by flowstone on the cave floor; (D) almost fully articulated, 622 covered by flowstone (NMNS-PV 23770).

623 Figure 3. Skeletal remains of Miniopterus sp. on the slopes of stalagmite in Cave A. (A) Heavily 624 covered by stalagmite; (B) More heavily covered by stalagmite, whose locality is shown in Fig. $6251 \mathrm{D}$.

626 Figure 4. Optic and SEM images of guano references and guano-like deposit in Hoshino Cave. 627 (A-C) Guano-like deposit (H180120g5) collected from Hoshino Cave, Minami-Daito Island; (D, 628 E) Modern guano (R2) collected in Taito, Chiba; (F, G) Fossil guano (R3) collected in Fujido 629 Cave, Gunma.

630 Figure 5. SEM and optical images of guano-like deposit in Cave A. (A, C) Fecal pellet-like 631 sample (Y180119g2). (B, D) Hydroxyapatite crust (Y160114g1), possibly derived from bat 632 feces.

633 Figure 6. FTIR spectra of guano references, guano-like deposits, and humic acid. (A) 634 Commercial fertilizer (R1); (B) Modern fecal pellet (R3); (C) Fossil guano (R4); (D, E) Guano635 like deposits sampled in Cave A; (F, G) Guano-like deposits sampled in Hoshino Cave; $(\mathrm{H})$ 636 humic acid (Dick et al., 2003); (I) humic acid extracted from municipal solid waste (Palumbo et 637 al., 2018). The numbers of Minami-Daito samples (4: Y180119g3, 5: Y180120g1, 6:

638 H180120g5) correspond to sampling localities in Figs. 1D-1E. u: upper, b: bottom. 
639 Figure 7. FTIR spectra of lateric soil, fissure-filled deposit, sampled deposits, and 640 hydroxyapatite. (A) Whole soil of Latosol (Dick et al., 2003); (B) Fissure-filled deposit; (C) 641 Guano-like deposit; (D) Hydroxyapatite crust; (E) Hydroxyapatite (Jayaweera et al., 2008). The 642 numbers of Minami-Daito samples (1: Fissure-filled deposit, 2: Y160114g1, 3: Y180119g2) 643 correspond to sampling localities in Fig. 1D.

644 Figure 8. Isotopic composition of carbon and nitrogen, total nitrogen by weight percent $(\% \mathrm{~N})$, 645 and $\mathrm{C}: \mathrm{N}$ ratio in the selected guano-like samples and guano references, corresponding to Table 2. 646 (A) Stable nitrogen isotope values vs. \%N; (B) Stable carbon isotope values vs. C:N. u: upper, 647 m: middle, b: bottom. Raw data are provided in Table S1. A full description of the bat guano 648 references (R1-R4) is in Supplementary Article S1.

649 Figure 9. Estimated $\delta^{13} \mathrm{C}$ values of vegetation based on bone apatite of cave-dwelling bats and 650 chronological ranges of the extirpated bats on Minami-Daito Island. (A) Estimated $\delta^{13} \mathrm{C}$ values 651 of vegetation on Minami-Daito Island, calculated from bone apatite $\delta^{13} \mathrm{C}$ values of the cave652 dwelling bats. Measured $\delta^{13} \mathrm{C}$ values of bone apatite are provided in Table 3. For the isotopic 653 enrichment factors and $\delta^{13} \mathrm{C}$ values of pure $\mathrm{C}_{3}$ - and $\mathrm{C}_{4}$-vegetation applied in this study, see 654 Supplementary Article S1 for details. (B) Estimated ages of the extirpated Minami-Daito bats 655 with lines of evidence revealed by this study. Thicker and darker lines indicate the time range 656 that is more strongly supported.

Table 1. A list of skeletal remains of Miniopterus sp. and Rhinolophus sp. collected from

661 Minami-Daito Island, Okinawa. At the National Museum of Nature and Science (Tokyo, Japan), 662 all vertebrate fossils cataloged in the Department of Geology and Paleontology start with the 663 prefix "NMNS-PV". 
665 Table 2. Summary of carbon and nitrogen isotopes, C:N ratios, weight percent of carbon and 666 nitrogen in guano-like samples.

667

668 Table 3. Stable carbon isotope values of bone apatite in the Minami-Daito cave-dwelling bats.

669

670 Supplementary Information

671 Table S1. Isotopic composition of carbon and nitrogen, total nitrogen by weight percent $(\% \mathrm{~N})$,

672 and $\mathrm{C}: \mathrm{N}$ ratio in selected guano-like samples and guano references, corresponding to Table 2 and 673 Fig. 8.

674 Table S2. Summary of radiocarbon ages (calBP) of a fossil guano reference and Minami-Daito 675 samples.

676

677

678

679

680

681

682 References

683

684 Albert JS, Schoolmaster DR, Tagliacollo V, Duke-Sylvester SM. 2017. Barrier displacement on 685 a neutral landscape: Toward a theory of continental biogeography. Systematic Biology 686 66(2): 167-182. DOI 10.1093/sysbio/syw080. 
688 Allentoft ME, Heller R, Oskam CL, Lorenzen ED, Hale ML, Gilbert MTP, Jacomb C, Holdaway

689 RN, Bunce M. 2014. Extinct New Zealand megafauna were not in decline before human

690 colonization. Proceedings of the National Academy of Sciences of the United States of

$691 \quad$ America 111(13): 4922-4927. DOI 10.1073/pnas.1314972111.

692

693

694 Bronk Ramsey C. 2009. Bayesian analysis of radiocarbon dates. Radiocarbon 51(1): 337-360.

695 DOI $10.1017 / \mathrm{S} 0033822200033865$.

696 Carpenter JK, Wilmshurst JM, McConkey KR, Hume JP, Wotton DM, Shiels AB, Burge OR, 697 Drake DR. 2020. The forgotten fauna: Native vertebrate seed predators on islands. Functional Ecology 34(9): 1802-1813. DOI 10.1111/1365-2435.13629.

699

700

Cerling TE, Harris JM, MacFadden BJ, Leakey MG, Quade J, Eisenmann V, Ehleringer JR.

701 1997. Global vegetation change through the Miocene/Pliocene boundary. Nature 389: 153-

702 158. DOI 10.1038/38229.

703

Chen SF, Juan C, Rossite S, Kinjo T, Fukui D, Kawai K, Tsang SM, Veluz MJ, Sakurai H, JangLiaw NH, Osawa K, Ko WY, Izawa M. 2021. Population genetic structure of the insular Ryukyu flying fox Pteropus dasymallus. Biotropica 3: 979211. DOI 10.1111/btp.12897. 
707 Dick DP, Santos JHZ, Ferranti EM. 2003. Chemical Characterization and Infrared Spectroscopy 708 of Soil Organic Matter from Two Southern Brazilian Soils. Revista Brasileira de Ciência do 709 Solo 27(1): 29-39. DOI 10.1590/s0100-06832003000100004.

710 Editorial Committee of the History of Minami-daito Village. 1990. [The History of Minami-daito 711 Village]. A revised edition. Minami-daito Village Office, Naha [in Japanese]

712 Ehime University Expedition Club. 1972. [Caves on Minami-Daito Island]. Report on the $8^{\text {th }}$ 713 Exploration of the Ryukyu Islands. [in Japanese]

714 Fiore S, Laviano R. 1991. Brushite, hydroxylapatite, and taranakite from Apulian caves 715 (southern Italy): New mineralogical data. American Mineralogist 76(9-10): 1722-1727.

716 Forbes MS., Bestland, EA. 2006. Guano-derived deposits within the sandy cave fills of

717 Naracoorte, South Australia. Alcheringa: An Australasian Journal of Palaeontology 1: 129-

718 146. DOI $10.1080 / 03115510609506859$.

719 Giurgiu A, Tămaş, T. 2013. Mineralogical data on bat guano deposits from three Romanian 720 caves. Studia Universitatis Babes-Bolyai, Geologia 58(2): 13-18. DOI 10.5038/1937$721 \quad 8602.58 .2 .2$

722 Google Earth V7.3.3.7786 (July 21, 2020) Minami-Daito, Okinawa, Japan. 25 50’27.86”N, 131

723 14'35.24”E, Eye alt 11.81km. Landsat/Copernicus, Maxar Technologies 2021, CNES/Airbus 724 2012. http://www.earth.google.com [accessed May 17, 2021]. 
725 Gratton C, Forbes AE. 2006. Changes in $\delta^{13} \mathrm{C}$ stable isotopes in multiple tissues of insect

726 predators fed isotopically distinct prey. Oecologia 147(4): 615-624. DOI 10.1007/s00442-

$727 \quad 005-0322-y$.

728 Hill CA, Forti P. 1997. Cave Minerals of the World, second edition. Huntsville, Alabama:

$729 \quad$ National Speleological Society, 463 p.

730

731

732

733

734

735

736

737

738

739

740

741

742

743

744

Inskeep WP, Silvertooth JC. 1998. Inhibition of hydroxyapatite precipitation in the presence of fulvic, humic, and tannic acids. Soil Science Society of America Journal 52: 941-946.

Jayaweera HDAC, Siriwardane I, de Silva KMN, de Silva RM. 2018. Synthesis of multifunctional activated carbon nanocomposite comprising biocompatible flake nano hydroxyapatite and natural turmeric extract for the removal of bacteria and lead ions from aqueous solution. Chemistry Central Journal 12(1): 1-14. DOI 10.1186/s13065-018-03847.

Kada Y. 2009. Remember sugarcane railway on Minami-Daito Island. In: [The People and Nature of Minami Daito Island]. Ed. Seiichi Nakai, Kazuaki Higashi and Daniel Long, 104-120. Kagoshima: Nampo Shinsha. [in Japanese]

Kaya M, Seyyar O, Baran T, Turkes T. 2014. Bat guano as new and attractive chitin and chitosan source. Frontiers in Zoology 11: 59. DOI 10.1186/s12983-014-0059-8.

Kinjo K. 2009. [Bats Living in a Remote Oceanic Island]. In: [The People and Nature of Minami Daito Island]. Ed. Seiichi Nakai, Kazuaki Higashi and Daniel Long, 138-150. Kagoshima: Nampo Shinsha. [in Japanese] 
745 Klein GV, Kobayashi K. 1980. Geological summary of the North Philippine Sea, based on Deep

746 Sea Drilling Project Leg 58 Results. In Klein GV, Kobayashi K., eds. Initial Reports of the

747 Deep Sea Drilling Project 58. U.S. Government Printing Office, 951-961. DOI

$748 \quad 10.2973 /$ dsdp.proc.58.144.1980.

749 Kohn MJ 2010. Carbon isotope compositions of terrestrial C3 plants as indicators of

750 (paleo)ecology and (paleo)climate. Proceedings of the National Academy of Sciences of the

751 United States of America 107(46): 19691-19695. DOI 10.1073/pnas.1004933107.

752 Méndez J. 1967. Organic compounds in humic acid extracts. Geoderma 1(1): 27-36. DOI

753 10.1016/0016-7061(67)90012-2.

754 Nakamoto A, Kinjo K, Izawa M. 2007. Food habits of Orii’s flying-fox, Pteropus dasymallus 755 inopinatus, in relation to food availability in an urban area of Okinawa-jima Island, the 756 Ryukyu Archipelago, Japan. Acta Chiropterologica 9(1): 237-249. DOI 10.3161/1733757 5329(2007)9[237:FHOOFP]2.0.CO;2.

758

759

760

761

762

763
Nambu A, Inagaki S, Ozawa S, Suzuki Y, Iryu Y. 2003. Stratigraphy of reef deposits on Kitadaito-jima, Japan. Journal of Geological Society of Japan 109(11): 617-634. [in Japanese with English summary]

Ohde S., Elderfield H. 1992. Strontium isotope stratigraphy of Kita-daito-jima Atoll, North Philippine Sea: implications for Neogene sea-level change and tectonic history. Earth and Planetary Science Letters 113(4): 473-486. DOI 10.1016/0012-821X(92)90125-F. 
764 Omori T, Yamazaki K, Itahashi Y, Ozaki H, Yoneda M. 2017. Development of a simple

765 automated graphitization system for radiocarbon dating at the University of Tokyo. 14th

766 International Conference on Accelerator Mass Spectrometry, University of Ottawa,

767 Canada.

768

769

770

771

772

773

774

775

776

777

778

779

780

781

782

783

784

Ota Y, Omura A, Koba M, Kawana T, Miyauchi T. 1991. Late Quaternary tectonic movements as deduced from raised coral reefs of Daito Islands on the northwestern part of Philippine Sea Plate. Journal of Geography 100(3): 317-336. [in Japanese with English summary]

Palumbo G, Schiavon M, Nardi S, Ertani A, Celano G, Colombo CM. 2018. Biostimulant potential of humic acids extracted from an amendment obtained via combination of olive mill wastewaters (OMW) and a pre-treated organic material derived from municipal solid waste (MSW). Frontiers in Plant Science 9: 1028. DOI 10.3389/fpls.2018.01028.

Podlesak DW, Torregrossa A-M, Ehleringer JR, Dearing MD, Passey BH, Cerling TE. 2008. Turnover of oxygen and hydrogen isotopes in the body water, $\mathrm{CO}_{2}$, hair, and enamel of a small mammal. Geochimica et Cosmochimica Acta 72: 19-35. DOI 10.1016/j.gca.2007.10.003.

RDB, 2020. [Japanese Red Data Book]. Japan Integrated Biodiversity Information System.

Reimer P, Austin WEN, Bard E, Bayliss A, Blackwell PG, Bronk Ramsey C, Butzin M, Cheng H, Lawrence Edwards R, Friedrich M, Grootes PM, Guilderson TP, Hajdas I, Heaton TJ, Hogg AG, Hughen KA, Kromer B, Manning SW, Muscheler R, ... Talamo, S. (2020). The IntCal20 Northern Hemisphere radiocarbon age calibration curve (0-55 cal kBP). Radiocarbon 62(4): 725-757. DOI 10.1017/RDC.2020.41. 
785 Salvarina I, Yohannes E, Siemers BM, Koselj K. 2013. Advantages of using fecal samples for 786 stable isotope analysis in bats: Evidence from a triple isotopic experiment. Rapid Communications in Mass Spectrometry 27(17): 1945-1953. DOI 10.1002/rcm.6649.

788 Schmidt MWI, Gleixner G. 2005. Carbon and nitrogen isotope composition of bulk soils,

789 particle-size fractions and organic material after treatment with hydrofluoric acid. European $790 \quad$ Journal of Soil Science 56(3): 407-416. DOI 10.1111/j.1365-2389.2004.00673.x.

791 Seno T, Maruyama S. 1984. Paleogeographic reconstruction and origin of the Philippine Sea.

792 Tectonophysics 102: 53-84. DOI 10.1016/0040-1951(84)90008-8.

793 Shimojana M. 1978. [Cave faunas on Minami- and Kita-daito-jima Islands and the southern part 794 of Okinawa-jima Island]. In: Board of Education, Okinawa Prefecture, ed. [Survey Report 795 796

Soto-Centeno JA, Steadman, DW. 2015. Fossils reject climate change as the cause of extinction of Caribbean bats. Scientific Reports 5: 7971. DOI 10.1038/srep07971.

Stevenson FJ. 1994. Humus Chemistry: Genesis, Composition, Reactions (2nd ed.). New York: 800 John Wiley \& Sons.

Stuiver M, Polach HA. 1977. Discussion reporting of ${ }^{14}$ C data. Radiocarbon 19(3): 355-363.

802 Tămaş T, Miheţ O, Giurgiu A. 2014. Mineralogy of bat guano deposits from Huda lui papară 803 cave (Trascău Mountains, Romania). Carpathian Journal of Earth and Environmental $804 \quad$ Sciences 9(3): 25-32. 
805 Urushibara-Yoshino K. 2012. Karstification processes on Minamidaito Island in the Nansei

806 Archipelago, southwest Japan. Bulletin of the Faculty of Letters, Hosei University 65: 83-

807 95. [in Japanese with English summary]

808 van der Geer A, Lyras G, de Vos J, Dermitzakis D. 2010. Evolution of Island Mammals:

809 Adaptation and Extinction of Placental Mammals on Islands. Oxford: Wiley-Blackwell.

$810 \quad$ DOI $10.1002 / 9781444323986$.

811 Vincenot CE, Collazo AM, Russo D. 2017. The Ryukyu flying fox (Pteropus dasymallus) - A

812 review of conservation threats and call for reassessment. Mammalian Biology 83: 71-77.

813 DOI 10.1016/j.mambio.2016.11.006.

814 Wood JR, Alcover JA, Blackburn TM, Bover P, Duncan RP, Hume JP, Louys J, Meijer HJM,

815 Rando JC, Wilmshurst JM. 2017. Island extinctions: Processes, patterns, and potential for

816 ecosystem restoration. Environmental Conservation 44(4):348-358. DOI

$817 \quad 10.1017 / \mathrm{S} 037689291700039 X$.

818

819 Wurster CM, Bird MI, Bull ID, Creed F, Bryant C, Dungait JAJ, Paz V. 2010. Forest contraction

820 in north equatorial Southeast Asia during the Last Glacial Period. Proceedings of the

$821 \quad$ National Academy of Sciences 107(35): 15508-15511. DOI 10.1073/pnas.1005507107.

822 Zhang W, Jiang S, Wang K, Wang L, Xu Y, Wu Z, Shao H, Wang Y, Miao M. 2015.

823 Thermogravimetric dynamics and FTIR analysis on oxidation properties of low-rank coal at 
824 low and moderate temperatures. International Journal of Coal Preparation and Utilization

$825 \quad 35(1): 39-50$. DOI 10.1080/19392699.2013.873421.

826 Ziegler AC, Howarth FG, Simmons NB. 2016. A second endemic land mammal for the

827 Hawaiian Islands: a new genus and species of fossil bat (Chiroptera: Vespertilionidae).

$828 \quad$ American Museum Novitates 3854: 1-52.

829

830

831

832

833

834

835 
Figure 1

Figure 1. Map of Minami-Daito Island, route map of a privately-owned Cave A, cave map of Hoshino Cave.

(A) Satellite map (Google Earth, 2020); (B) Map of Ryukyu Islands; (C) Entrance of Cave A; (D)

Route map of Cave A; (E) Map of Hoshino Cave (Simplified from a map of Ehime University Expedition Club, 1972). Solid circles indicate sampling localities of guano-like deposits, and open stars indicate sampling localities of cave-dwelling bat bones. 

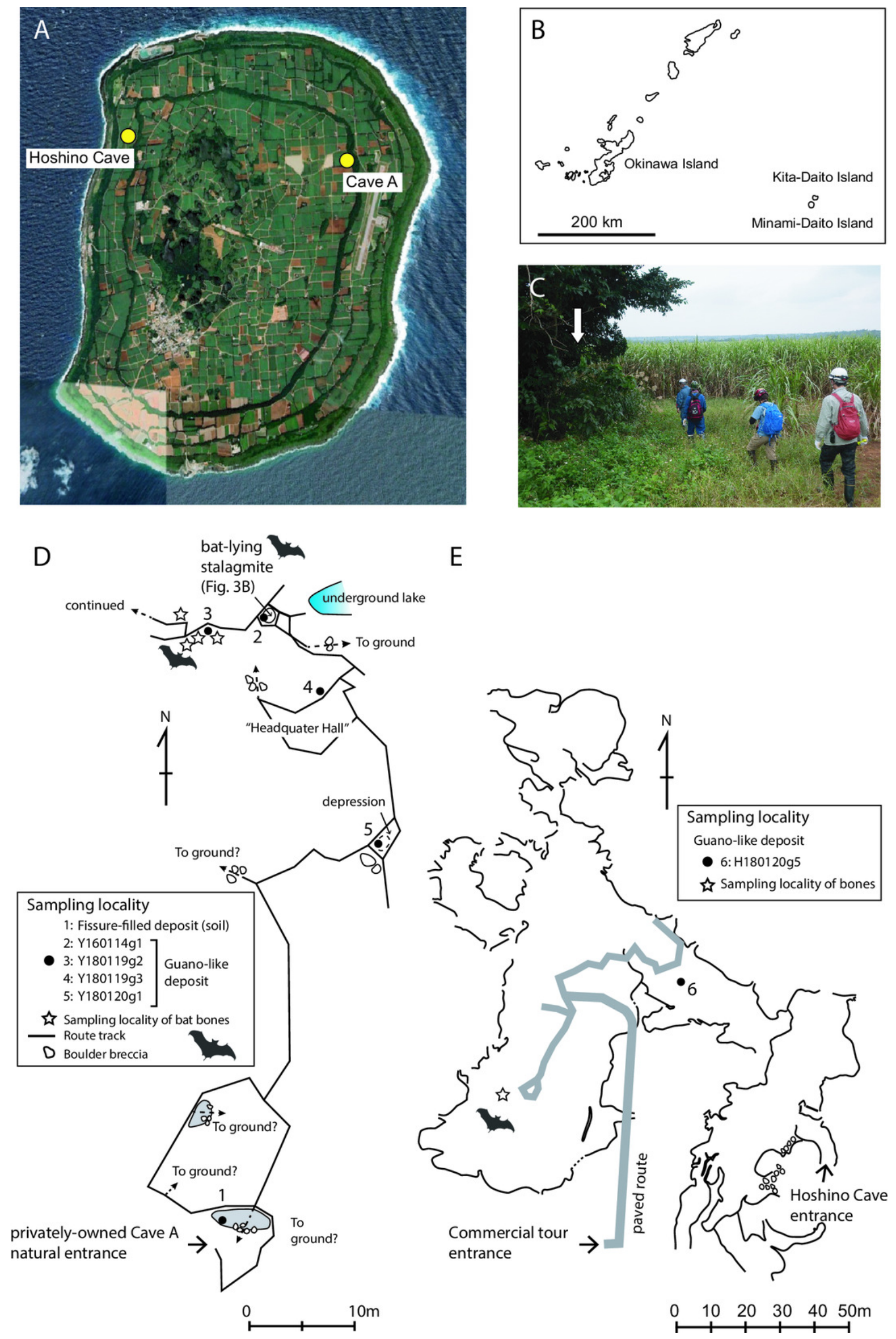
Figure 2

Figure 2. Various conditions of skeletal remains of Miniopterus sp.

(A) partially articulated, not covered by flowstone; (B) complete skull with fragmentary bones, not covered by flowstone; (C) partially articulated, covered by flowstone on the cave floor; (D) almost fully articulated, covered by flowstone (NMNS-PV 23770). 

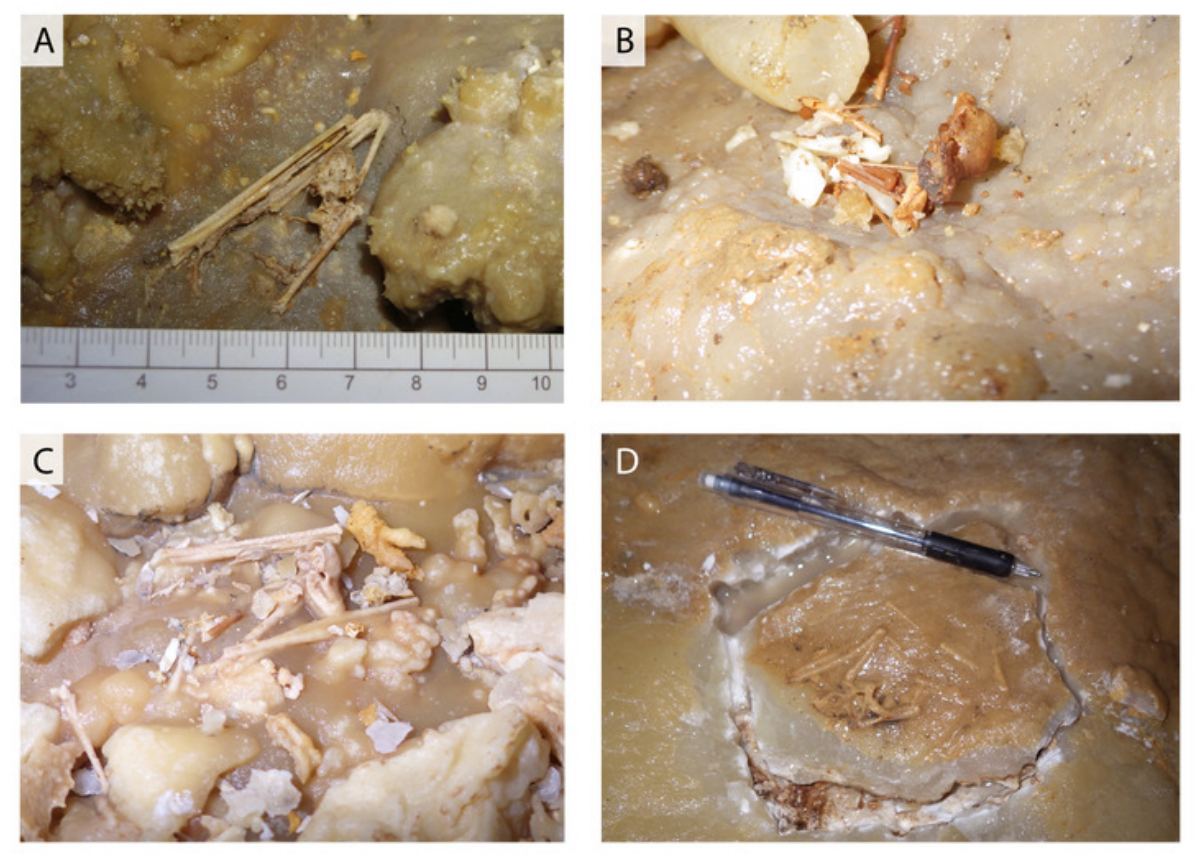
Figure 3

Figure 3. Skeletal remains of Miniopterus sp. on the slopes of stalagmite in Cave A.

(A) Heavily covered by stalagmite; (B) More heavily covered by stalagmite, whose locality is shown in Fig. 1D. 

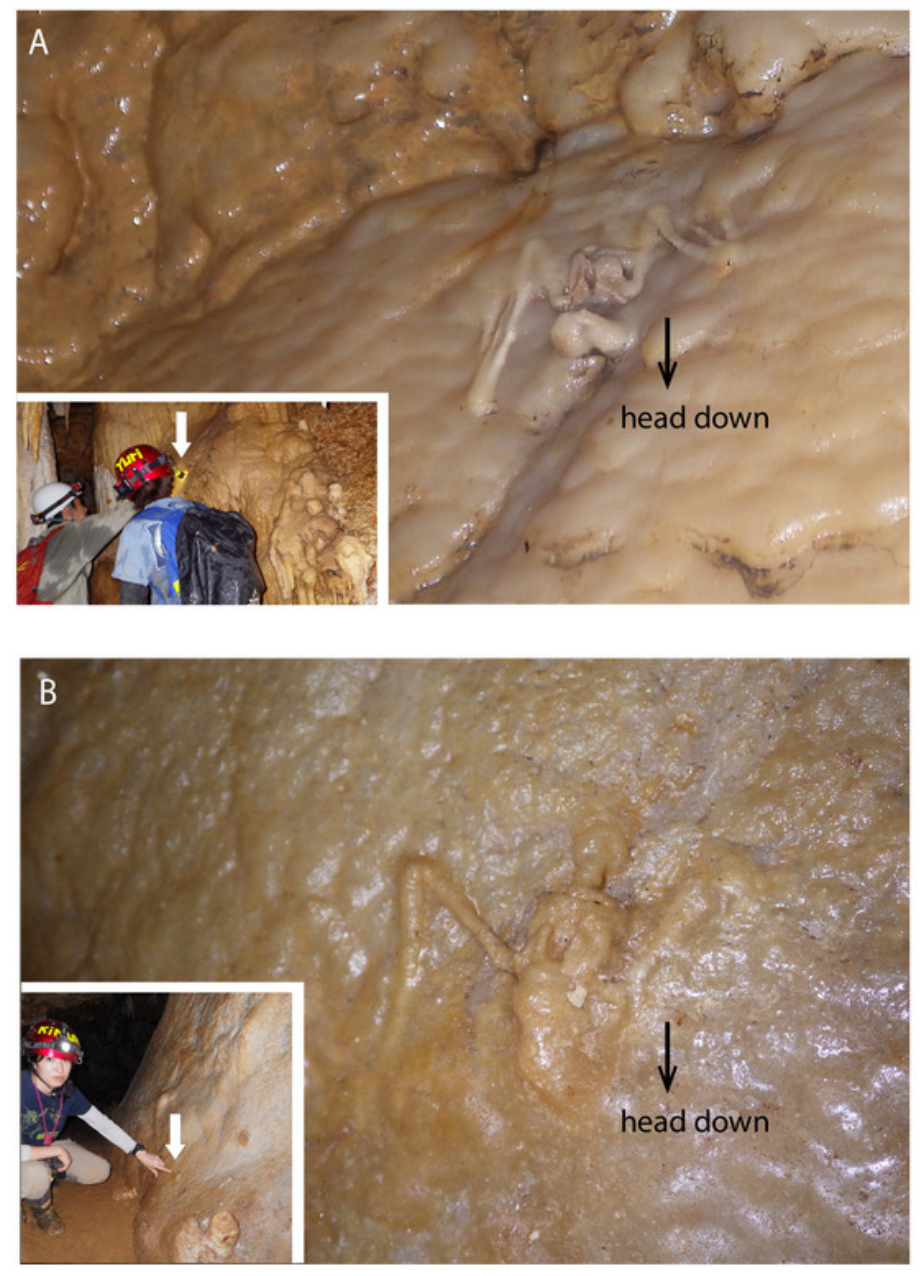


\section{Figure 4}

Figure 4. Optic and SEM images of guano references and guano-like deposit in Hoshino Cave.

(A-C) Guano-like deposit (H180120g5) collected from Hoshino Cave, Minami-Daito Island; (D, E) Modern guano (R2) collected in Taito, Chiba; $(F, G)$ Fossil guano (R3) collected in Fujido Cave, Gunma. 

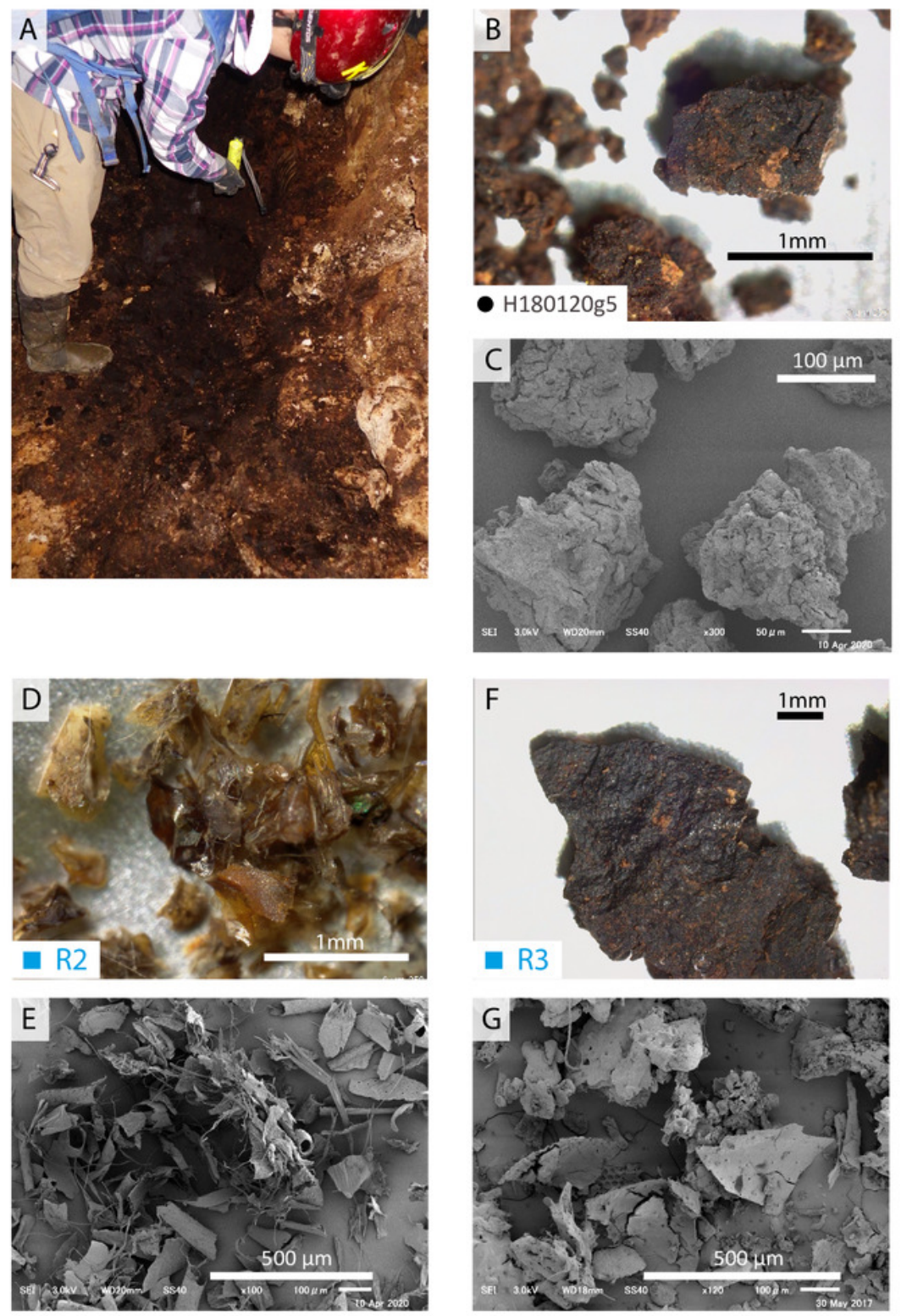
Figure 5

Figure 5. SEM and optical images of guano-like deposit in Cave A.

(A, C) Fecal pellet-like sample (Y180119g2). (B, D) Hydroxyapatite crust (Y160114g1), possibly derived from bat feces. 

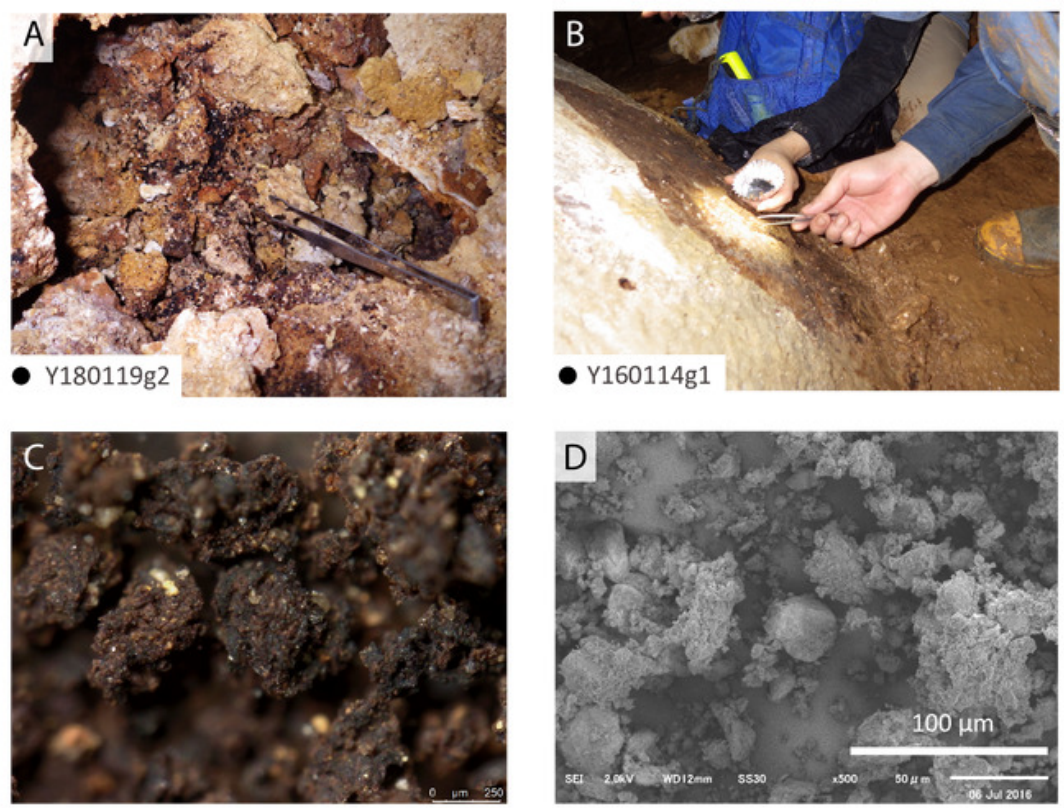


\section{Figure 6}

Figure 6. FTIR spectra of guano references, guano-like deposits, and humic acid.

(A) Commercial fertilizer (R1); (B) Modern fecal pellet (R3); (C) Fossil guano (R4); (D, E) Guano-like deposits sampled in Cave A; $(F, G)$ Guano-like deposits sampled in Hoshino Cave; (H) humic acid (Dick et al., 2003); (I) humic acid extracted from municipal solid waste (Palumbo et al., 2018). The numbers of Minami-Daito samples (4: Y180119g3, 5: Y180120g1, 6: H180120g5) correspond to sampling localities in Figs. 1D-1E. u: upper, b: bottom. 


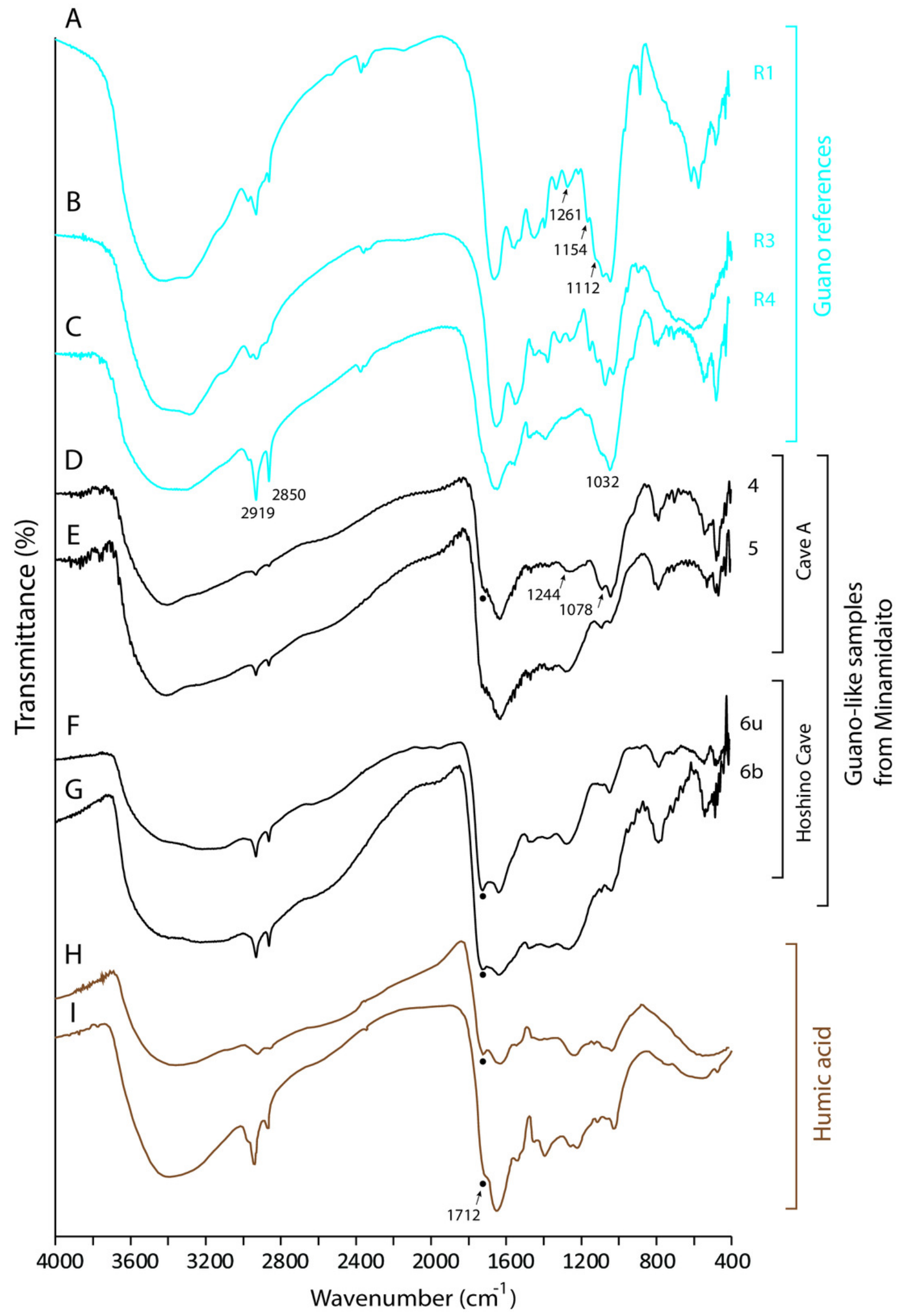

PeerJ reviewing PDF | (2021:07:64153:1:0:NEW 20 Nov 2021) 


\section{Figure 7}

Figure 7. FTIR spectra of lateric soil, fissure-filled deposit, sampled deposits, and hydroxyapatite.

(A) Whole soil of Latosol (Dick et al., 2003); (B) Fissure-filled deposit; (C) Guano-like deposit;

(D) Hydroxyapatite crust; (E) Hydroxyapatite (Jayaweera et al., 2008). The numbers of

Minami-Daito samples (1: Fissure-filled deposit, 2: Y160114g1, 3: Y180119g2) correspond to sampling localities in Fig. 1D. 


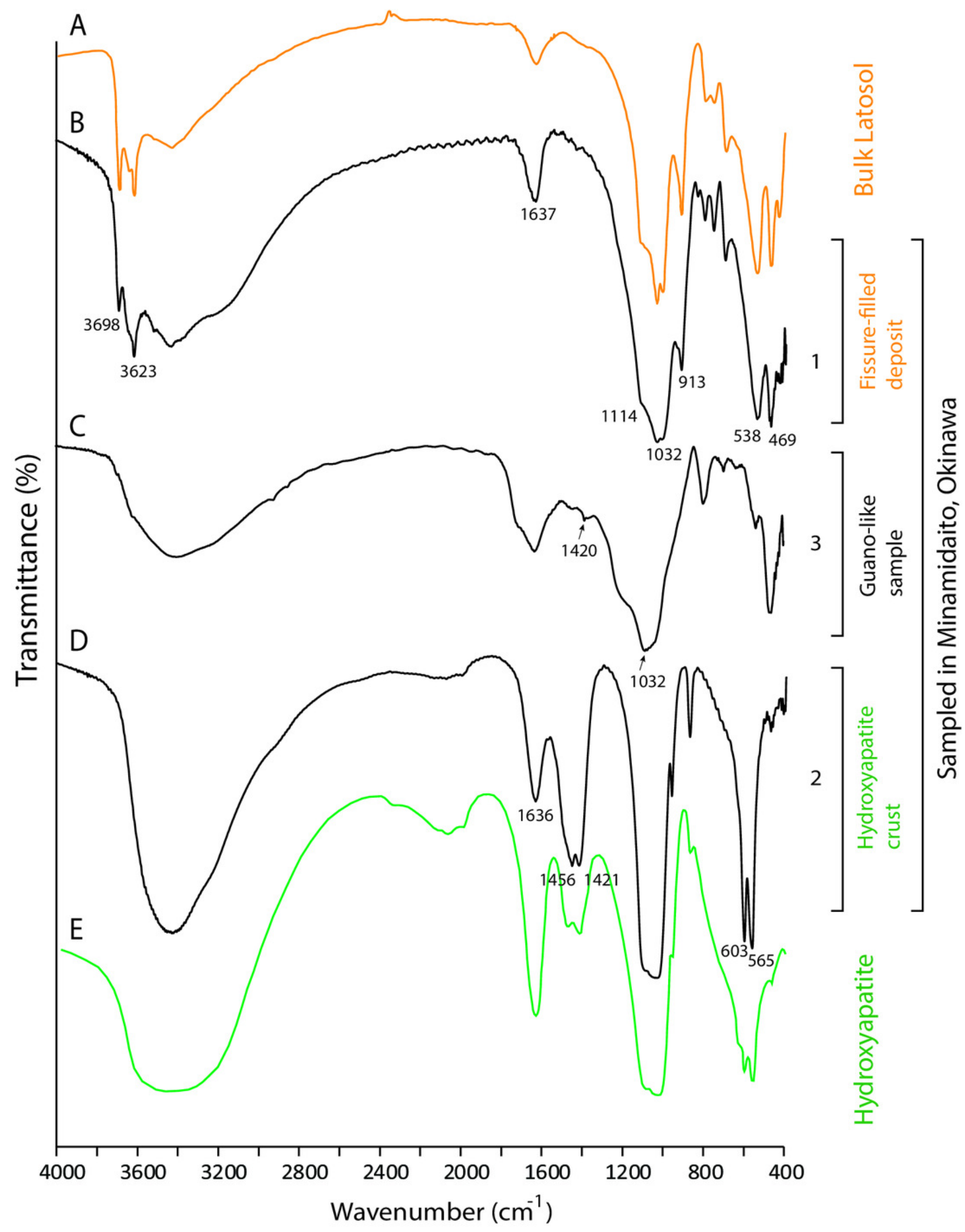


Figure 8

Figure 8. Isotopic composition of carbon and nitrogen, total nitrogen by weight percent $(\% \mathrm{~N})$, and $\mathrm{C}: \mathrm{N}$ ratio in the selected guano-like samples and guano references, corresponding to Table 2 .

(A) Stable nitrogen isotope values vs. \%N; (B) Stable carbon isotope values vs. C:N. u: upper, m: middle, b: bottom. Raw data are provided in Table S1.
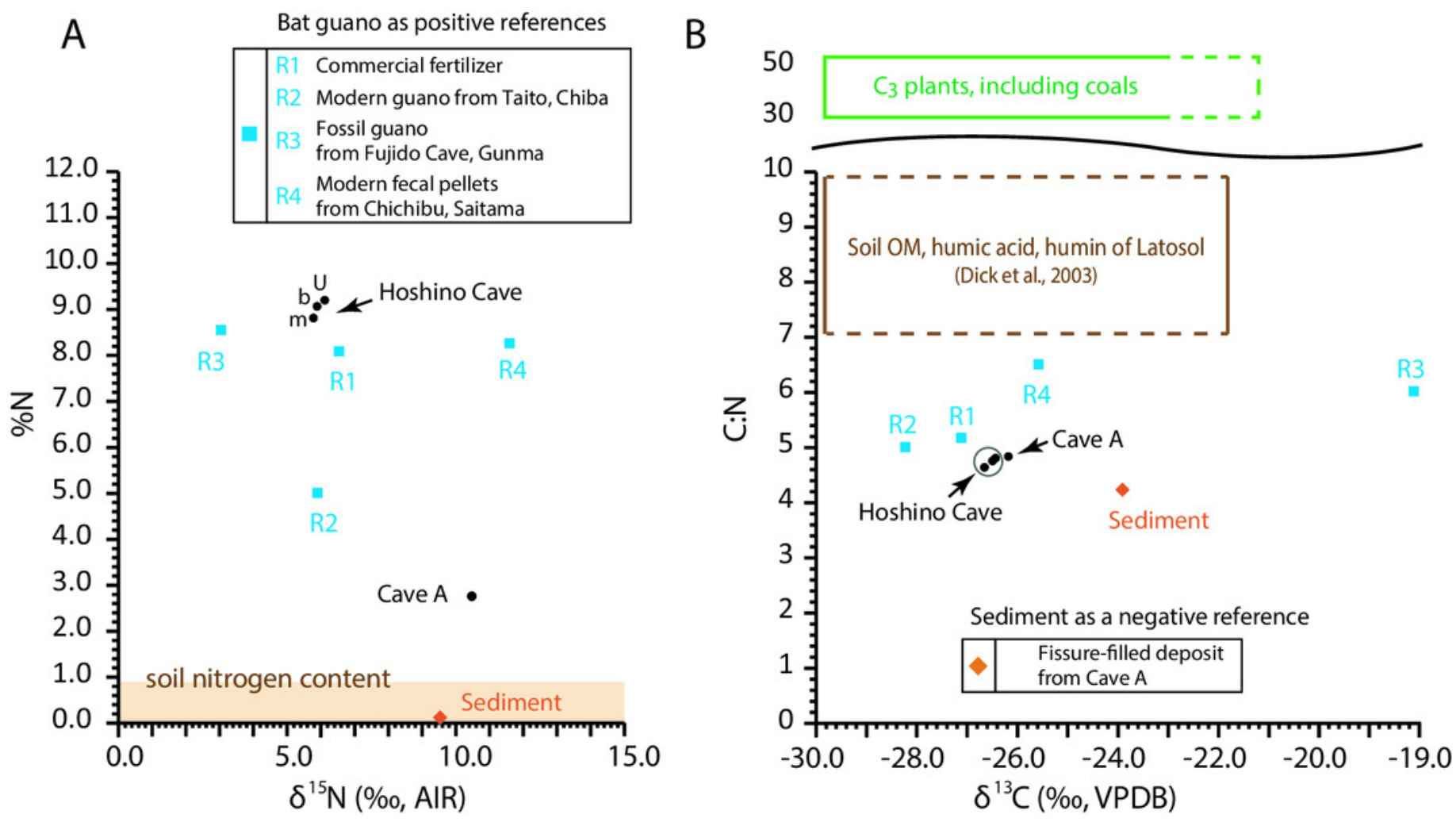


\section{Figure 9}

Estimated $\delta^{13} \mathrm{C}$ values of vegetation based on bone apatite of cave-dwelling bats and chronological ranges of the extirpated bats on Minami-Daito Island.

(A) Estimated $\delta^{13} \mathrm{C}$ values of vegetation on Minami-Daito Island, calculated from bone apatite $\delta^{13} \mathrm{C}$ values of the cave-dwelling bats. Measured $\delta^{13} \mathrm{C}$ values of bone apatite are provided in Table 3. For the isotopic enrichment factors and $\delta^{13} \mathrm{C}$ values of pure $\mathrm{C}_{3}$ - and $\mathrm{C}_{4}$-vegetation applied in this study, see Supplementary Article S1 for details. (B) Estimated ages of the extirpated Minami-Daito bats with lines of evidence revealed by this study. Thicker and darker lines indicate the time range that is more strongly supported. 


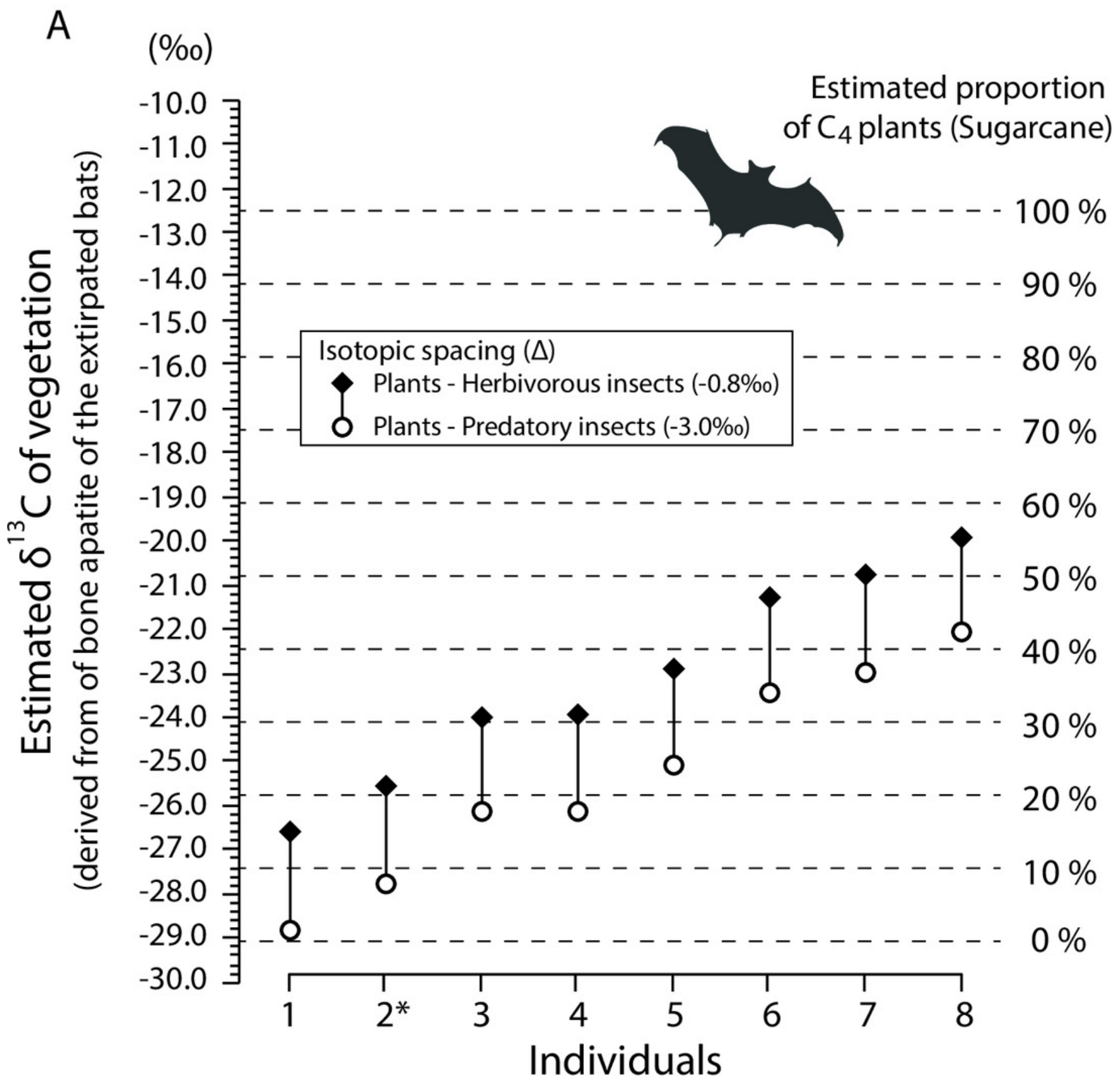

B

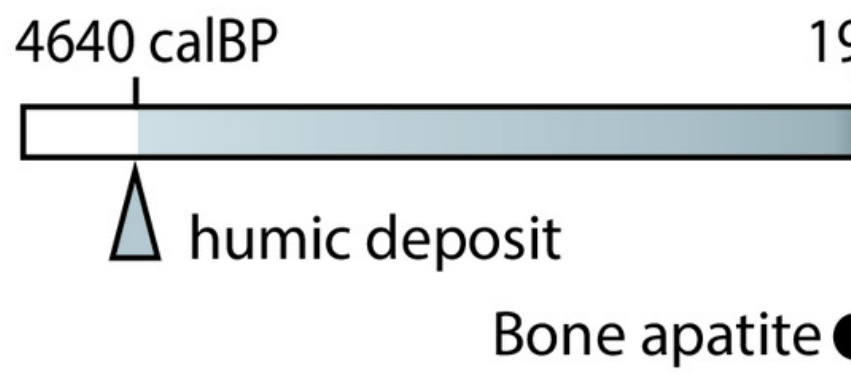




\section{Table $\mathbf{1}$ (on next page)}

Table 1. A list of skeletal remains of Miniopterus sp. and Rhinolophus sp. collected from Minami-Daito Island, Okinawa.

At the National Museum of Nature and Science (Tokyo, Japan), all vertebrate fossils catalogued in the Department of Geology and Paleontology start with the prefix "NMNS-PV". 
Table 1

\begin{tabular}{|c|c|c|c|c|c|c|}
\hline $\begin{array}{c}\text { Museum } \\
\text { ID } \\
\text { (NMNS-PV) }\end{array}$ & NMNS-PV branch number & Scientific name & $\begin{array}{l}\text { Estimated \# of } \\
\text { individual }\end{array}$ & Identification & Cave & Field Sampling ID \\
\hline 23770 & & Miniopterus sp. & 1 & Articulated body & Cave A & NA \\
\hline 23771 & & Miniopterus sp. & 1 & Articulated body & Cave A & NA \\
\hline \multirow{8}{*}{23772} & 1 & \multirow{8}{*}{ Rhinolophus sp. } & \multirow{8}{*}{1} & Left maxilla with two molars (partial) & \multirow{8}{*}{ Hoshino Cave } & H160114-01-G \\
\hline & 2 & & & Left mandible with teeth (m1-m3) & & H160114-01-A \\
\hline & 3 & & & $\begin{array}{l}\text { Right mandible without teeth (partial, } \\
\text { fragmented) }\end{array}$ & & H160114-01-F \\
\hline & 4 & & & Left radius (partial) & & H160114-01-C \\
\hline & 5 & & & Radius? (partial) & & H160114-01-E \\
\hline & 6,7 & & & Pelvic bone (fragment), rib (partial), & & H160114-01-B \\
\hline & 8 & & & Left humerus (almost complete) & & H160114-01-D \\
\hline & NA & & & $\begin{array}{l}\text { Skull (zygomatic arch only), bone } \\
\text { fragments }\end{array}$ & & H160114-01-H \\
\hline \multirow{11}{*}{23773} & 1 & \multirow{11}{*}{ Rhinolophus sp. } & \multirow{11}{*}{1} & Left maxilla with teeth (partial) & \multirow{11}{*}{ Cave A } & Y160113-10-C \\
\hline & 2 & & & Left mandible (fragment) & & Y160113-10-G \\
\hline & $3,4,5,6,7,8,9$ & & & Right mandible with teeth (fragmented) & & Y160113-10-B \\
\hline & 10 & & & Left clavicle (complete) & & Y160113-10-D \\
\hline & 11 & & & Left radius (fragment) & & Y160113-10-H \\
\hline & 12 & & & $\begin{array}{l}\text { Radius? (fragment, small rod branched } \\
\text { off), bone fragments }\end{array}$ & & Y160113-10-J \\
\hline & 13 & & & Left humerus (partial) & & Y160113-10-I \\
\hline & 14 & & & $\begin{array}{l}\text { Pelvic bone (almost complete), bone } \\
\text { fragment }\end{array}$ & & Y160113-10-A \\
\hline & 15 & & & Metacarpal or phalange (partial)? & & Y160113-10-E \\
\hline & 16 & & & Metacarpal? (partial) & & Y160113-10-K \\
\hline & NA & & & Bone fragment (could not identified by YK) & & Y160113-10-F \\
\hline
\end{tabular}




\begin{tabular}{|c|c|c|c|c|c|c|}
\hline & NA & & & Bone fragments & & Y160113-10-L \\
\hline \multirow{7}{*}{23774} & 1 & \multirow{7}{*}{ Miniopterus sp. } & \multirow{7}{*}{1} & Left radius (fragment) & \multirow{7}{*}{ Cave A } & Y160113-04-B \\
\hline & 2 & & & Right radius (complete) & & Y160113-04-D \\
\hline & 3 & & & Left humerus (fragment) & & Y160113-04-E \\
\hline & 4 & & & Right humerus (complete) & & Y160113-04-C \\
\hline & 5 & & & Metacarpal (fragment) & & Y160113-04-J \\
\hline & 6,7 & & & Metacarpal or phalange? (fragments) & & Y160113-04-A \\
\hline & NA & & & Bone fragments & & Y160113-04-G \\
\hline 23775 & & Miniopterus sp. & 1 & Right radius (complete) & Cave A & Y160113-05-A \\
\hline 23776 & & Miniopterus sp. & 1 & Right radius (almost complete) & Cave $\mathrm{A}$ & Y160113-06-A \\
\hline \multirow{6}{*}{23777} & 1 & \multirow{6}{*}{ Miniopterus sp. } & \multirow{6}{*}{1} & Skull & \multirow{6}{*}{ Cave A } & Y160113-08-F \\
\hline & 2 & & & Left radius (partial) & & Y160113-08-A \\
\hline & 3 & & & Left humerus (complete) & & Y160113-08-E \\
\hline & 4 & & & Right humerus (fragment) & & Y160113-08-D \\
\hline & 5 & & & Metacarpal (fragment) & & Y160113-08-G \\
\hline & NA & & & Bone fragments & & Y160113-08-B \\
\hline \multirow{7}{*}{23778} & 1 & \multirow{7}{*}{ Miniopterus sp. } & \multirow{7}{*}{1} & Skull (partial, fragment) without teeth & \multirow{7}{*}{ Cave A } & Y160113-03-A \\
\hline & $2,3,4,5,6,7,8$ & & & Isolated teeth & & Y160113-03-B \\
\hline & 9 & & & Right dentary wo teeth & & Y160113-03-K \\
\hline & $10,11,12,13,14,15,16,18,19,20,21$ & & & Left dentary, five islated teeth & & Y160113-03-I \\
\hline & 22 & & & Isolated tympanic bulla (partial) & & Y160113-03-C \\
\hline & 23,24 & & & $\begin{array}{l}\text { Scapula (fragment), skull (zygomatic arch } \\
\text { only) }\end{array}$ & & Y160113-03-N \\
\hline & 25 & & & Right radius (fragment) & & Y160113-03-C \\
\hline
\end{tabular}




\begin{tabular}{|c|c|c|c|c|c|c|}
\hline & 26 & & & Right humerus & & Y160113-03-H \\
\hline & $27,28,29$ & & & Metacarpal & & Y160113-03-E \\
\hline & 30 & & & $\begin{array}{l}\text { Metacarpal, metacarpal or phalange? } \\
\text { (fragments) }\end{array}$ & & Y160113-03-F \\
\hline & 31 & & & Metacarpal (fragment) & & Y160113-03-J \\
\hline & 32 & & & Metacarpal or phalange? (fragment) & & Y160113-03-M \\
\hline & $33,34,35,36$ & & & Rib & & Y160113-03-D \\
\hline & NA & & & $\begin{array}{l}\text { Bone fragment (radius, left or right } \\
\text { unidentified) }\end{array}$ & & Y160113-03-G \\
\hline & NA & & & $\begin{array}{l}\text { Bone fragment (radius, left or right } \\
\text { unidentified) }\end{array}$ & & Y160113-03-L \\
\hline & NA & & & Bone fragments & & Y160113-03-P \\
\hline \multirow{10}{*}{23779} & 1 & \multirow{10}{*}{ Miniopterus sp. } & \multirow{10}{*}{1} & $\begin{array}{l}\text { Skull (maxilla with ful dentition, others } \\
\text { fragmented) }\end{array}$ & \multirow{10}{*}{ Cave A } & Y160114-01-A \\
\hline & 2 & & & $\begin{array}{l}\text { Right mandible with dentition (almost } \\
\text { complete) }\end{array}$ & & Y160114-01-G \\
\hline & 3 & & & Isolated antemolar & & Y160114-01-G \\
\hline & 4 & & & Atlas (complete) & & Y160114-01-E \\
\hline & 5 & & & Left radius (fragment) & & Y160114-01-C \\
\hline & 6 & & & Right radius (almost complete) & & Y160114-01-F \\
\hline & 7 & & & Left humerus (complete) & & Y160114-01-B \\
\hline & 8 & & & Right humerus (complete) & & Y160114-01-D \\
\hline & 9 & & & Left femur (complete) & & Y160114-01-H \\
\hline & NA & & & Bone fragments & & Y160114-01-I \\
\hline \multirow{4}{*}{23780} & 1 & \multirow{4}{*}{ Miniopterus sp. } & \multirow{4}{*}{1} & Skull & \multirow{4}{*}{ Cave A } & Y160114-02-A \\
\hline & 2 & & & Left mandible & & Y160114-02-D \\
\hline & $3,4,5$ & & & Axis, cervical bones & & Y160114-02-F \\
\hline & 6 & & & Thoracic vertebrate (partial) & & Y160114-02-J \\
\hline
\end{tabular}




\begin{tabular}{|c|c|c|c|c|c|c|}
\hline & 7 & & & Clavicle (complete) & & Y160114-02-I \\
\hline & 8 & & & Left scapula (partial) & & Y160114-02-G \\
\hline & 9 & & & Left radius (complete) & & Y160114-02-H \\
\hline & 10 & & & $\begin{array}{l}\text { Left humerus (fused with other bones by } \\
\text { calcite crystals) }\end{array}$ & & Y160114-02-E \\
\hline & 11 & & & Right humerus (partial) & & Y160114-02-B \\
\hline & 12,13 & & & Metacarpals (partial) & & Y160114-02-C \\
\hline & $14,15,16,17,18,19,20$ & & & Ribs & & Y160114-02-K \\
\hline & NA & & & Metacarpals or carpal (fragment) & & Y160114-02-M \\
\hline & NA & & & Bone fragment & & Y160114-02-L \\
\hline \multirow{12}{*}{23781} & 1 & \multirow{12}{*}{ Miniopterus sp. } & \multirow{12}{*}{1} & Skull (partial), skull fragments & \multirow{12}{*}{ Cave A } & Y160114-03-A \\
\hline & $2,3,4,5,6,7$ & & & temparate bullae, isolated teeth & & Y160114-03-I \\
\hline & 8 & & & Left radius (complete) & & Y160114-03-C \\
\hline & 9 & & & Right radius (complete) & & Y160114-03-B \\
\hline & 10 & & & Left humerus (fragment) & & Y160114-03-H \\
\hline & 11 & & & Right humerus (complete) & & Y160114-03-G \\
\hline & 12 & & & Right femur & & Y160114-03-E \\
\hline & 13 & & & Metacarpal (partial) & & Y160114-03-D \\
\hline & 14 & & & Metacarpal (partial) & & Y160114-03-J \\
\hline & 15 & & & Metacarpal (partial) & & Y160114-03-K \\
\hline & 16 & & & Metacarpal (partial) & & Y160114-03-L \\
\hline & NA & & & Metacarpal (fragment) & & Y160114-03-F \\
\hline \multirow{3}{*}{23782} & 1 & \multirow{3}{*}{ Miniopterus sp. } & \multirow{3}{*}{1} & Left maxila with dentition (partial) & \multirow{3}{*}{ Cave A } & Y160114-04-E \\
\hline & 2,3 & & & $\begin{array}{l}\text { Left dentary with dentition (complete), } \\
\text { isolated } \mathrm{m} 1 \text { (trigonid basin only) }\end{array}$ & & Y160114-04-C \\
\hline & 4,5 & & & $\begin{array}{l}\text { Right dentary with dentition (complete), } \\
\text { isolated antemolar }\end{array}$ & & Y160114-04-D \\
\hline
\end{tabular}




\begin{tabular}{|c|c|c|c|c|c|c|}
\hline & 6 & & & Right radius (partial) & & Y160114-04-B \\
\hline & NA & & & Metacarpal or phalange (fragments) & & Y160114-04-A \\
\hline & NA & & & Bone fragments & & Y160114-04-F \\
\hline \multirow{9}{*}{23783} & 1 & \multirow{9}{*}{ Miniopterus sp. } & \multirow{9}{*}{2} & Left radius (partial) & \multirow{9}{*}{ Cave A } & Y160113-07-B \\
\hline & 2 & & & Left? radius (fragment) & & Y160113-07-D \\
\hline & 3 & & & Right radius (complete) & & Y160113-07-E \\
\hline & 4 & & & Right? radius (fragment) & & Y160113-07-K \\
\hline & 5 & & & Left humerus (complete) & & Y160113-07-F \\
\hline & 6 & & & Left humerus (complete) & & Y160113-07-A \\
\hline & 7 & & & Right humerus (complete) & & Y160113-07-G \\
\hline & 8 & & & Right humerus, bone fragment & & Y160113-07-C \\
\hline & NA & & & Metacarpal or phalange? (bone fragments) & & Y160113-07-H \\
\hline 23784 & & Miniopterus sp. & 1 & $\begin{array}{l}\text { Left and right mandibles (complete, } \\
\text { separated) }\end{array}$ & Cave A & \\
\hline 23785 & & Miniopterus sp. & 1 & Right maxilla with dentition (partial) & Cave $\mathrm{A}$ & \\
\hline 24999 & & Miniopterus sp. & 1 & Left mandible (partial) & Cave A & \\
\hline 25000 & & Miniopterus sp. & 1 & Right mandible (partial) & Cave $\mathrm{A}$ & \\
\hline
\end{tabular}




\section{Table 2 (on next page)}

Table 2. Summary of carbon and nitrogen isotopes, $\mathrm{C}: \mathrm{N}$ ratios, weight percent of carbon and nitrogen in samples. 
Table 2

\begin{tabular}{|c|c|c|c|c|c|c|c|c|c|c|c|c|c|}
\hline \multirow{2}{*}{ Sample ID } & \multirow{2}{*}{ Material Type } & \multirow{2}{*}{ Sampling locality } & \multirow{2}{*}{$\mathrm{N}$} & \multicolumn{2}{|c|}{$\delta C(\%$, VPDB) } & \multicolumn{2}{|c|}{$\delta N(\%, A I R)$} & \multicolumn{2}{|c|}{$\mathrm{C} / \mathrm{N}$} & \multicolumn{2}{|c|}{$\% \mathrm{C}$ in sample } & \multicolumn{2}{|c|}{$\% \mathrm{~N}$ in sample } \\
\hline & & & & Average & SD & Average & SD & Average & SD & Average & SD & Average & SD \\
\hline R1 & Modern guano (R1) & Commercial fertilizer & 5 & -27.1 & 0.22 & 6.5 & 0.37 & 5.2 & 0.24 & 41.8 & 1.0 & 8.1 & 0.5 \\
\hline R2 & Modern guano (R2) & Taito, Chiba & 1 & -28.2 & & 5.9 & & 5.0 & & 44.8 & & 8.9 & \\
\hline R3 & Modern fecal pellet (R3) & Chichibu, Saitama & 3 & -19.1 & 0.03 & 3.0 & 0.10 & 6.0 & 0.02 & 51.1 & 0.4 & 8.6 & 0.1 \\
\hline R4 & Fossil guano (R4) & Fujido Cave, Ueno, Gunma & 1 & -25.6 & & 11.6 & & 6.5 & & 53.8 & & 8.3 & \\
\hline Sediment & $\begin{array}{l}\text { Fissure-filled cave } \\
\text { deposit }\end{array}$ & $\# 1$ in Cave $A$ & 7 & -23.9 & 0.15 & 9.5 & 0.17 & 4.2 & 0.24 & 0.5 & 0.03 & 0.1 & 0.002 \\
\hline Y180119g2 & Fecal pellet-like sample & $\# 3$ in Cave A & 1 & -26.1 & & 10.2 & & 4.8 & & 13.2 & & 2.7 & \\
\hline H180120g5-u & Guano-like deposit & \#6 in Hoshino Cave & 1 & -26.4 & & 6.1 & & 4.8 & & 44.3 & & 9.2 & \\
\hline H180120g5-m & Guano-like deposit & \#6 in Hoshino Cave & 1 & -26.7 & & 5.8 & & 4.6 & & 40.9 & & 8.8 & \\
\hline H180120g5-b & Guano-like deposit & \#6 in Hoshino Cave & 1 & -26.5 & & 5.9 & & 4.8 & & 43.2 & & 9.1 & \\
\hline
\end{tabular}

3 


\section{Table 3(on next page)}

Stable carbon isotope values of bone apatite in the Minami-Daito cave-dwelling bats. 
1 Table 3

2

\begin{tabular}{|c|l|c|l|}
\hline Individual \# & Element & $\delta^{13} \mathrm{C}(\%, \mathrm{VPDB})$ & Lab Code \\
\hline 1 & Proximal end of right humerus & -15.0 & $\mathrm{Y} 160113 \mathrm{~b}-6$ \\
\hline 2 & Multiple bone fragments & -14.0 & $\mathrm{Y} 160113 \mathrm{~b}-201902-4-2$ \\
\hline 3 & Distal end of right humerus & -12.4 & $\mathrm{Y} 160113 \mathrm{~b}-8$ \\
\hline 4 & Left radius & -12.3 & $\mathrm{Y} 160113 \mathrm{~b}-201902-1$ \\
\hline 5 & Right radius & -11.3 & $\mathrm{Y} 160113 \mathrm{~b}-201902-2-2$ \\
\hline 6 & Distal end of humerus & -9.6 & $\mathrm{Y} 160113 \mathrm{~b}-5$ \\
\hline 7 & Proximal end of femur & -9.1 & $\mathrm{Y} 160113 \mathrm{~b}-7$ \\
\hline 8 & Fragments of left humerus and left radius & -8.3 & $\mathrm{Y} 160113 \mathrm{~b}-201902-3-2$ \\
\hline
\end{tabular}

